\title{
REVIEW
}

\section{Mouse models of endocrine tumors}

\author{
Manuel D Gahete1,2,3,4,5, Juan M Jiménez-Vacas1,2,3,4,5, Emilia Alors-Pérez1,2,3,4,5, Vicente Herrero-Aguayo1,2,3,4,5, \\ Antonio C Fuentes-Fayos 1,2,3,4,5, Sergio Pedraza-Arévalo1,2,3,4,5, Justo P Castaño1,2,3,4,5 and Raúl M Luque1,2,3,4,5 \\ ${ }^{1}$ Maimonides Institute for Biomedical Research of Cordoba (IMIBIC), Córdoba, Spain \\ 2Department of Cell Biology, Physiology, and Immunology, Universidad de Córdoba, Córdoba, Spain \\ ${ }^{3}$ Reina Sofia University Hospital, Córdoba, Spain \\ ${ }^{4}$ CIBER Fisiopatología de la Obesidad y Nutrición (CIBERobn), Córdoba, Spain \\ ${ }^{5}$ Agrifood Campus of International Excellence (ceiA3), Córdoba, Spain
}

Correspondence should be addressed to M D Gahete or J P Castaño or R M Luque: bc2gaorm@uco.es or justo@uco.es or raul.Iuque@uco.es

\begin{abstract}
Endocrine and neuroendocrine tumors comprise a highly heterogeneous group of neoplasms that can arise from (neuro)endocrine cells, either from endocrine glands or from the widespread diffuse neuroendocrine system, and, consequently, are widely distributed throughout the body. Due to their diversity, heterogeneity and limited incidence, studying in detail the molecular and genetic alterations that underlie their development and progression is still a highly elusive task. This, in turn, hinders the discovery of novel therapeutic options for these tumors. To circumvent these limitations, numerous mouse models of endocrine and neuroendocrine tumors have been developed, characterized and used in preclinical, co-clinical (implemented in mouse models and patients simultaneously) and post-clinical studies, for they represent powerful and necessary tools in basic and translational tumor biology research. Indeed, different in vivo mouse models, including cell line-based xenografts (CDXs), patientderived xenografts (PDXs) and genetically engineered mouse models (GEMs), have been used to delineate the development, progression and behavior of human tumors. Results gained with these in vivo models have facilitated the clinical application in patients of diverse breakthrough discoveries made in this field. Herein, we review the generation, characterization and translatability of the most prominent mouse models of endocrine and neuroendocrine tumors reported to date, as well as the most relevant clinical implications obtained for each endocrine and neuroendocrine tumor type.
\end{abstract}

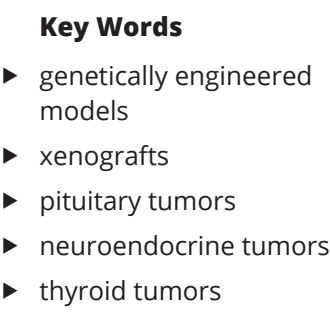

Journal of Endocrinology (2019) 240, R73-R96

\section{Endocrine and neuroendocrine tumors: origin, location, heterogeneity and outcome}

Cancer and tumor pathologies represent one of the main health problems for the population worldwide, with incidence and death ratios still increasing (Rusner et al. 2013, Goswamy et al. 2016, Siegel et al. 2018). For this reason, more basic, translational and clinical studies are needed to identify novel markers to improve diagnostics and prognosis assessment and new therapeutic targets (Capdevila et al. 2017). Among tumor pathologies, endocrine and neuroendocrine tumors represent a unique group of neoplasms, which arise from (neuro)endocrine cells, either from endocrine glands or from the widespread diffuse neuroendocrine system. Therefore, endocrine and neuroendocrine tumors are widely distributed throughout the body and display a heterogeneous nature (Oberg 2018), with some of them exhibiting increasing incidence (Oberg et al. 2013, Dasari et al. 2017). Current 
evidence indicates that, in addition to comprise an ample and diverse group of neoplasias, endocrine and neuroendocrine tumors are extremely heterogeneous, a feature that deeply influences their diagnosis, prognosis and medical management, and profoundly hampers the identification of novel and more general biomarkers and/or therapeutic targets. The basis for this heterogeneity resides in the variety of locations, cells of origin, genetic background, molecular fingerprints, functional abilities and clinical features exhibited by these tumors, which is translated to the patients bearing these diseases (Oberg et al. 2013, Capdevila et al. 2017, Giordano 2018, Oberg 2018, Pedraza-Arevalo et al. 2018).

In particular, endocrine and neuroendocrine tumors include those tumors arising mainly from cells located at the pituitary (including somatotropinomas, prolactinomas, corticotropinomas, etc.), thyroid (including medullary, papillary or follicular thyroid carcinomas), adrenal gland (including adrenocortical adenomas and carcinomas) or comprising the neuroendocrine system (which can be subdivided according to their location in foregut (lungs, thymus, esophagus, stomach, duodenum and pancreas), midgut (jejunum, ileum and cecum) and hindgut (distal colon and rectum)) (Giordano 2018). This original location of the tumor is essential to define tumor characteristics and clinical management, as it greatly influences other additional tumor characteristics such as the possible cell types of origin, the molecular mechanisms underlying their development and/or progression or the accompanying clinical features. Regardless of their location, endocrine and neuroendocrine tumors can exhibit a variety of histological types, from well-differentiated and low-grade tumors to poorly differentiated and high-grade lesions. Likewise, they can course with diverse clinical features: from non-symptomatic tumors, only presenting nonspecific symptoms at the time of diagnosis, to functioning tumors, which can present symptoms related to the specific hormone secreted by the tumor, and, usually, translate into a corresponding disease or syndrome, such as acromegaly in somatotropinomas, Cushing's disease in corticotropinomas or carcinoid syndrome in serotoninproducing neuroendocrine tumors. Endocrine and neuroendocrine tumors are also highly heterogeneous from a molecular and genetic perspective. In fact, although two molecular pathways have been found to be prominently altered in many endocrine and, particularly, neuroendocrine tumors (mammalian target of rapamycin (mTOR) and Notch pathways), other crucial pathways have been found to be altered in particular tumor types, as KRAS, HRAS and NRAS in non-small-cell lung carcinomas or retinoblastoma 1 (RB1) in small-cell lung carcinoma (SCLC) (Oberg 2018). In addition, endocrine and neuroendocrine tumors are among the neoplasms with a more marked heritable component, being associated with at least ten different genetic syndromes, including multiple endocrine neoplasia type 1 and 2 (MEN1 and MEN2), neurofibromatosis type 1 (NF1) or Von HippelLindau (VHL) syndrome (Crona \& Skogseid 2016).

All these levels of complexity found in endocrine and neuroendocrine tumors can be understood as a series of superimposed layers of heterogeneity, which have complicated their systematic and comprehensive study (Pedraza-Arevalo et al. 2018). Indeed, this heterogeneity, together with the limited incidence of some of these tumor types, drastically hampers the possibility of implementing high-scale translational and clinical studies. In this scenario, mouse models have emerged as a powerful and essential tool in basic and translational tumor biology research (Day et al. 2015, Gengenbacher et al. 2017, Kersten et al. 2017), specially in the case of endocrine and neuroendocrine tumors (Basham et al. 2016, Lines et al. 2016, Mohr \& Pellegata 2017, Vitale et al. 2017). There are numerous examples of breakthrough discoveries in preclinical mouse tumor models that paved the way for clinical application in humans, such as the first demonstration of the efficacy of immune checkpoint blockade for the treatment of tumor pathologies (Leach et al. 1996). Indeed, this valuable association is further supported by the fact that preclinical models and cancer therapies have usually co-evolved accordingly, wherein this evolution was highly dependent on technical advances (Day et al. 2015). In this sense, studies in mouse models can contribute to improved clinical trials, identifying potentially effective therapies but also predicting positive or detrimental effects in molecular subtypes, being used in pre- or co-clinical studies (Pietras \& Hanahan 2005, Raymond et al. 2011).

\section{Mouse models for tumor pathologies}

In vivo mouse models are potent and crucial tools in basic and translational tumor biology research that have being used to delineate the development, progression and behavior of human tumors, including endocrine and neuroendocrine tumors. These mouse models include cell line-based xenografts (CDX), patient-derived xenografts (PDX), environmentally induced models and genetically engineered mouse (GEMs) models (Day et al. 2015, Gengenbacher et al. 2017, Kersten et al. 2017). 
Much of the current knowledge about cancer and its hallmarks derives from the establishment of longterm in vitro cultured tumor cell lines, and on their in vivo inoculation in mice. In fact, these models remain the most commonly used mouse models in basic and translational cancer research (Gengenbacher et al. 2017). Specifically, cell line-based tumor models represent classical prototypes of tumor development and have long been used in academic research and industry to analyze tumor growth and response to treatment. In these models, tumor cells can be injected ectopically (mostly subcutaneously), orthotopically (to mimic tumor growth in its organ of origin) or systemically (mostly intraperitoneally, intravenously or intracardially) to study metastatic spread by using syngeneic immunocompetent inbred mice (allografts) or immunocompromised mice (xenografts). In all cases, these models exhibit important limitations, mainly derived from the strong selection process. First, CDX models exhibit a tissue architecture that is severely perturbed with clear alterations in the microenvironment compared with human tumors, including changes in the vascular, lymphatic and immune components, also due to their rapid growth (Sikder et al. 2003, Frese \& Tuveson 2007). Second, these CDX models also present loss of genetic heterogeneity and irreversible changes in gene expression due to the long-term in vitro propagation (Daniel et al. 2009, Gillet et al. 2011). However, although CDX models are greatly reductionist, their easy technical manipulability, low cost and synchronous tumor growth enable the application of these models for quick identification and validation of relevant genes in tumor biology, as well as for preclinical evaluation of experimental treatments (Day et al. 2015, Gengenbacher et al. 2017, Kersten et al. 2017).

PDXs are also typically generated by subcutaneous implantation of fresh, surgically derived human tumor explants into immune-deficient mice (Tentler et al. 2012). However, PDXs have been shown to retain, at least during limited time of in vivo growth, the molecular, genetic and histopathological features of their originating tumors (Hidalgo et al. 2014). Indeed, the PDXs are the only current model system able to directly incorporate the enormous inter-patient and intra-tumor heterogeneity that is inherent to human cancer, and thus, represent a promising tool for personalized medicine. In this regard, inasmuch as PDXs are derived from human tumors, they may serve to directly evaluate clinically approved drugs and, in fact, they seem to be able to faithfully predict therapy responses when comparing retrospectively drug responses in patients and their corresponding xenografts
(Siolas \& Hannon 2013). For these reasons, the so-called co-clinical trials are aiming to establish PDXs from patients who are enrolled in clinical trials, which may be used concomitantly to explore numerous therapeutic alternatives from an individualized perspective. However, PDX studies remain hindered by several limitations. Likely, the most important handicap is the fact that the engraftment rate strongly varies between different tumor types and grades, and it is dependent on the recipient mouse strain and original patient sample quality (Landis et al. 2013). This engraftment variability limits the genetic complexity represented by PDXs, in that tumor samples from patients with poor prognosis exhibit higher engraftment rate and, therefore, this capacity may even serve as a predictive biomarker (Eirew et al. 2015). In addition, as mentioned above, in these mouse models, the human stroma is initially present in the tumor engrafted, but it is ultimately replaced by mouse stroma components following in vivo passaging (Sivanand et al. 2012). Finally, these tumor models require an immunocompromised background, which precludes their use to study immune system influence and to analyze immunotherapeutic strategies (Zitvogel et al. 2016).

Environmentally induced models are based on environmental cancer-causing agents, including chemicals, radiation and pathogens, which are identified to be carcinogenic in animals, through standardized approaches as the carcinogen bioassay (Kemp 2015). Remarkably, these environmental models exhibit de novo tumor growth, represent all stages of multistep carcinogenesis and closely recapitulate the phenotypic and genetic heterogeneity of their human counterparts, at least in many cases (Steele \& Lubet 2010, Nassar et al. 2015, Westcott et al. 2015). However, despite their biological relevance, these models are scarcely used in cancer research (Gengenbacher et al. 2017), likely due to the inherently long latency and high variability of penetrance of the induced tumors, which precludes their use in experimental research.

Finally, genetically engineered mouse (GEM) models have emerged as the second most common type of mouse model in oncology research (Gengenbacher et al. 2017). This is due to the increasing understanding of the genetic aberrations underlying tumorigenesis, which has enabled the generation of different GEM models that reproduce the genetic events observed in human cancers, allowing de novo tumor formation in a native immunoproficient microenvironment. Accordingly, these models faithfully recapitulate the molecular and histopathological features of human cancers and exhibit a robust predictive power 
for drug response and resistance (Kersten et al. 2017). For these reasons, GEM models have been used in co-clinical trials, wherein parallel treatments of multiple genetically defined mouse cohorts may be used for patient stratification by identifying genetic biomarkers (Zitvogel et al. 2016).

\section{Mouse models of endocrine and neuroendocrine tumors}

All the in vivo cancer-associated mouse models defined above have been or are being currently used to study different aspects of the biology of endocrine and neuroendocrine tumors. Though, it should be mentioned that the generation of CDX and PDX models depends on the existence of cell lines and patient samples available to be inoculated in the appropriate model, and the environmentally induced models are scarcely used to study these types of tumors. In contrast, several different GEM models have been generated and are widely used to model endocrine and neuroendocrine tumors as it is described below (Tables 1 and 2).

\section{Models of (neuro)endocrine tumor syndromes}

The molecular bases of endocrine and neuroendocrine tumors are strongly related to genomic instability and mutations. Although the majority of them are sporadic, a significant percentage may arise in a context of familial inherited syndromes (Oberg 2013). In this sense, one of the first described syndromes associated to the presence of these tumors was the multiple endocrine neoplasia type 1 or MEN1, an autosomal dominantly inherited complex endocrine syndrome, caused by mutations in MEN1 gene, which encodes menin protein. MEN1 syndrome is mostly associated to the appearance of pancreatic, parathyroid and pituitary tumors (Thakker 2014). The mouse models developed to study this syndrome are exclusively based on mutations in Men1 gene (Mohr \& Pellegata 2017) and, therefore, the putative use of PDX models could represent a substantial advance in the near future (Table 1). Remarkably, all these mouse models of MEN1 syndrome show a remarkable overlap with the human syndrome in terms of pathologically relevant features, as recently reviewed (Mohr \& Pellegata 2017), and therefore represent ideal models to explore different aspects of this endocrine syndrome. The initial works were focused on Men1 systemic knockout models, which were generated by different combinations of exons 1-8 deletions, but these modifications resulted in embryonic lethality (Piret $\&$ Thakker 2011). For this reason, heterozygous mice were subsequently used, which presented tumors from 9 months of age in several glands, including pancreas, pituitary, parathyroid, thyroid, adrenal or gonads. These heterozygous Men1-knockout mouse models have been used to analyze different aspects of the disease, including microvascular alterations, since these tumors have been found to be one of the most vascularized type of tumors (Chu et al. 2013), and, more recently, to explore the

Table 1 Description of the main GEM models used in the study of endocrine syndromes.

\begin{tabular}{|c|c|c|c|c|c|}
\hline $\begin{array}{l}\text { Endocrine } \\
\text { syndrome }\end{array}$ & Model name & Tumor type & Model type & Gene (promoter*) & References \\
\hline \multirow[t]{3}{*}{ MEN1 } & $\mathrm{MEN1}^{+/-}$ & $\begin{array}{l}\text { Pancreatic NET } \\
\text { Pituitary } \\
\text { Parathyroid } \\
\text { Thyroid } \\
\text { Adrenal } \\
\text { Gonadal }\end{array}$ & $\begin{array}{l}\text { Heterozygous } \\
\text { knockout }\end{array}$ & Men1 & Piret \& Thakker (2011) \\
\hline & PTH-MEN & Parathyroid & $\begin{array}{l}\text { Homozygous } \\
\text { knockout }\end{array}$ & Men1 $\left(P \operatorname{th}{ }^{*}\right)$ & Libutti et al. (2003) \\
\hline & PDX1-MEN & Pancreatic NET & $\begin{array}{l}\text { Homozygous } \\
\text { knockout }\end{array}$ & $\operatorname{Men} 1\left(P d x 1^{*}\right)$ & Quinn et al. (2012) \\
\hline MEN2A & CT-RET & MTC & $\begin{array}{l}\text { Homozygous } \\
\text { knockout }\end{array}$ & $\operatorname{Ret}\left(C T / C G R P^{*}\right)$ & Pestourie et al. (2010) \\
\hline MEN2B & RET-KO & $\begin{array}{l}\text { Pheochromocytoma } \\
\text { MTC }\end{array}$ & $\begin{array}{l}\text { Homozygous } \\
\text { knockout }\end{array}$ & Ret & Smith-Hicks et al. (2000) \\
\hline NF1 & $\mathrm{NF} 1^{+/-}$ & Pheochromocytoma & $\begin{array}{l}\text { Heterozygous } \\
\text { knockout }\end{array}$ & $N f 1$ & $\begin{array}{l}\text { Lepoutre-Lussey et al. } \\
\text { (2016) }\end{array}$ \\
\hline VHL & NES-VHL & Paraganglioma & $\begin{array}{l}\text { Homozygous } \\
\text { knockout }\end{array}$ & Vhl $\left(\right.$ Nes $\left.^{*}\right)$ & Merlo et al. (2017) \\
\hline \multicolumn{6}{|c|}{ *Driver promoter in the case of knockout models. } \\
\hline \multicolumn{6}{|c|}{$\begin{array}{l}\text { https://joe.bioscientifica.com } \\
\text { https://doi.org/10.1530/JOE-18-0571 }\end{array}$} \\
\hline
\end{tabular}


Table 2 Description of the main GEM models used in the study of endocrine and neuroendocrine tumors.

\begin{tabular}{l} 
Model name \\
\hline $\begin{array}{l}\text { Pituitary tumors } \\
\text { Men1TS/+ }\end{array}$ \\
GHRH-MT \\
aGSU.PTTGXRb+/- \\
Cdkn1 ${ }^{+/-}$ \\
Prkar1a ${ }^{+/-}$ \\
p18INK4c \\
Aip ${ }^{+/-}$ \\
Tg-PCE;p27Kip1-/- \\
HMGA1 \\
HMGA2 \\
p19Ink4d
\end{tabular}

AVP/SV40

CRH-MT

Crh-120/+

$\mathrm{Rb}^{+/-} ; \operatorname{Ini} 1^{+/-}$

PyLT-1

POMC-SV40

p18-1-

p18-/-;p27-/-

hFSH $\beta$-SV40tsTag

$\alpha G S U-P T T G$

\begin{tabular}{|c|c|}
\hline $\mathrm{p} 18 / \alpha \mathrm{SU}$ & Thyrotropinoma \\
\hline $\mathrm{Rb}^{+/-} ;{\mathrm{Tp} 53^{+/-}}^{-}$ & Undefined \\
\hline $\mathrm{Rb}^{+/-;} ; \mathrm{Tp} 53^{-/-}$ & Undefined \\
\hline$R b^{+/-;} ; A R F-1-^{-}$ & Undefined \\
\hline $\mathrm{Rb}^{-/-}$ & Undefined \\
\hline Cdk4R/R;p27-/- & Undefined \\
\hline
\end{tabular}

Prolactinoma

Thyrotropinoma

Prolactinoma

Prolactinoma

Prolactinoma

Prolactinoma

Prolactinoma Non-functioning

adenomas

Model type

Heterozygous knockout

Transgenic Somatotropinoma

Gonadotropinoma

Somatotropinoma

Corticotropinoma

Somatotropinoma

Somatotropinoma

Somatotropinoma

Somatotropinoma

Somatotropinoma

Somatotropinoma

Somatotropinoma

Somatotropinoma

Gonadotropinomas

Somatotropinoma

Corticotropinoma

Corticotropinoma

Corticotropinoma

Corticotropinoma

Corticotropinoma

Corticotropinoma

Corticotropinoma

Corticotropinoma

Gonadotropinoma

Gonadotropinoma

Transgenic

Double homozygous knockout

Double heterozygous knockout

Homozygous + heterozygous

knockout

Homozygous + heterozygous

knockout

Homozygous knockout

Knock-in + homozygous knockout
Gene (promoter*)

Men1

$\operatorname{GHRH}\left(M T^{*}\right)$

PTTG $\left(\alpha S U^{*}\right)$

$R b$

$C d k n 1 b$

Prkar1a

Cdkn2c

Aip

Cyclin E

Tp27

HMGA1(Cmv*)

HMGA2 (Cmv*)

p19

$\operatorname{SV} 40(A V P *)$

$C R H\left(M t^{*}\right)$

CRH (mutCrh*)

$R b$

Ini1

PyLT (polyoma early Helseth et al. (1992) region*)

PyLT-SV40 (POMC*) Low et al. (1993)

Tp18

Tp18

Tp27

SV40 (FSHb*)

Franklin et al. (1998)

$\operatorname{PTTG}\left(\alpha S U^{*}\right)$

Tp18

$\alpha S U$

$R b$

Tp53

$R b$

Tp53

$R b$

Arf

$R b^{-/-}$

$C d k 4^{R / R}$

Cdkn1b
Franklin et al. (1998)

Kumar et al. (1998)

Crabtree et al. (2001),

Biondi et al. (2002)

Asa et al. (1992)

Chesnokova et al. (2005), Donangelo et al. (2006)

Fero et al. (1996), Kiyokawa et al. (1996), Nakayama et al. (1996)

Franklin et al. (1998)

Raitila et al. (2010)

Roussel-Gervais et al. (2010)

Fedele et al. (2005)

Fedele et al. (2002)

Bai et al. (2014)

Stefaneanu et al. (1992)

Stenzel-Poore et al. (1992)

Bentley et al. (2014)

Guidi et al. (2006)

Abbud et al. (2005), Donangelo et al. (2006)

Lloyd et al. (2002)

Harvey et al. (1995)

Harvey et al. (1995)

Tsai et al. (2002)

Vooijs et al. (1998),

Vooijs et al. (2002)

Sotillo et al. (2005) 
Table 2 Continued.

\begin{tabular}{|c|c|c|c|}
\hline Model name & Tumor type & Model type & Gene (promoter*) \\
\hline Ink4c/p53-null & Undefined & Double homozygous knockout & $\begin{array}{l}\text { Ink4c } \\
\text { Arf }\end{array}$ \\
\hline \multicolumn{4}{|l|}{ Thyroid tumors } \\
\hline RET/PTC3 & PTC & Transgenic & Ret/Ptc3 $(\operatorname{Tg} *)$ \\
\hline RET/PTC1 & PTC & Transgenic & Ret/Ptc1 (Tg*) \\
\hline TRK-T1 & PTC & Transgenic & $\operatorname{Trk}-T 1(\operatorname{Tg} *)$ \\
\hline $\mathrm{N}$-RASQ61K & PTC & Transgenic & $N-\operatorname{Ras} Q 61 K(\operatorname{Tg} *)$ \\
\hline BRAFv600e & PTC & Transgenic & $\operatorname{Brafv600e}\left(\operatorname{Tg}^{*}\right)$ \\
\hline TrR $\beta-P V$ & FTC & Transgenic & $\operatorname{TRbPV/PV}\left(\operatorname{Tg}^{*}\right)$ \\
\hline R1a-TpoKO & FTC & Tissue-specific knockout & Prkar1a (Tpo*) \\
\hline Rap1bGV12-LoxP-N17 & FTC & Transgenic + goitrogens & $\operatorname{Rap} 1 b^{G 12 V}\left(T g^{*}\right)$ \\
\hline PtenL/L-TPO-Cre & FTC & Tissue-specific knockout & Pten $($ Tpo*) \\
\hline Pten-PPFP & FTC & $\begin{array}{l}\text { Transgenic + homozygous } \\
\text { knockout }\end{array}$ & $\begin{array}{l}\text { Ppfp }(\text { Tpo*) } \\
\text { Pten }\end{array}$ \\
\hline [Pten, p53]thyr-/- & ATC & Double tissue-specific knockout & $\begin{array}{l}\text { Tp53 } \\
\text { Pten }\end{array}$ \\
\hline ret/PTC1+;p53-/- & ATC & $\begin{array}{l}\text { Transgenic + homozygous } \\
\text { knockout }\end{array}$ & Ret-Ptc1 (Tg*) Tp53 \\
\hline RET/PTC3;p53-/- & ATC & $\begin{array}{l}\text { Transgenic + homozygous } \\
\text { knockout }\end{array}$ & Ret-Ptc3 (Tg*) Tp53 \\
\hline ThrbPV/PV;KrasG12D & ATC & Double transgenic & $\begin{array}{l}\operatorname{TrR\beta }-P V(\operatorname{Tg} *) \\
K-\operatorname{Ras} A S G 12 D(\operatorname{Tg} *)\end{array}$ \\
\hline 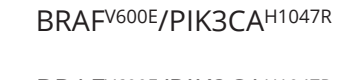 & ATC & Double transgenic & $\begin{array}{l}\text { Brafurooee }\left(\operatorname{Tg}^{*}\right) \\
\text { PIK3CA } 11047 R\end{array}$ \\
\hline BRAFV600E/PIK3CA & ATC & $\begin{array}{l}\text { Transgenic + homozygous } \\
\text { knockout }\end{array}$ & $\begin{array}{c}\text { Brafu600e }(\text { Tpo*) } \\
\text { Tp53 (Tpo*) }\end{array}$ \\
\hline CT/RET & MTC & Transgenic & $\operatorname{Ret}^{\mathrm{C} 634 R}\left(\mathrm{Ct} / \operatorname{Cgrp}^{*}\right)$ \\
\hline CALC-MEN2B-RET & MTC & Transgenic & $\operatorname{Ret}^{M 918 T}\left(\mathrm{Ct} / \mathrm{Cgrp}{ }^{*}\right)$ \\
\hline p25OE & MTC & Transgenic & p25 (Nse*) \\
\hline $\mathrm{Rb}^{-/-} \mathrm{p} 53^{-/-}$ & MTC & Double homozygous knockout & $\begin{array}{l}R b \\
T p 53\end{array}$ \\
\hline \multicolumn{4}{|l|}{ Adrenal gland tumors } \\
\hline Nr5a1+/- & ACT & Heterozygous knockout & Nr5a1 \\
\hline YAC-TR & $\mathrm{ACT}$ & Transgenic & $\operatorname{Nr5a1}\left(Y A C^{*}\right)$ \\
\hline FAdE-SF1 & Pediatric ACT & Transgenic & $\operatorname{Nr5a1}($ FAdE*) \\
\hline $\mathrm{Apc}^{+/-}$ & ACC & Heterozygous knockout & $A p c$ \\
\hline APC KO & ACC & Heterozygous knockout & $\operatorname{Apc}\left(\mathrm{Sf} 1-\mathrm{Cre}{ }^{*}\right)$ \\
\hline PEPCK-IGF-II & ACC & Transgenic & IGF2 (PEPCK*) \\
\hline Adlgf2 & ACC & Transgenic & $\lg f 2\left(\mathrm{Akrb} 17^{*}\right)$ \\
\hline$H 19 \triangle D M D$ & ACC & $\begin{array}{l}\text { Transgenic + heterozygous } \\
\text { knockout }\end{array}$ & $\begin{array}{l}\text { Apc } \\
\text { lgf } 2 / H 19 \text { ICR }\end{array}$ \\
\hline Acdacd/acd;p53+/- & ACC & Sporadic mutation & $\begin{array}{l}\text { Acd } \\
\text { Tp53 }\end{array}$ \\
\hline P540scc-SV40 & ACC & Transgenic & $\begin{array}{l}\text { SV40-Tag } \\
(\text { P450scc*) }\end{array}$ \\
\hline AdTAg & ACC & Transgenic & SV40-Tag $\left(A k r 1 b 7^{*}\right)$ \\
\hline \multicolumn{4}{|l|}{$\begin{array}{l}\text { Pulmonary neuroendocrine } \\
\text { tumors }\end{array}$} \\
\hline RB-TP53-KO & $\begin{array}{l}\text { SCLC } \\
\text { LCNEC }\end{array}$ & Double homozygous knockout & $\begin{array}{l}R b \\
T p 53\end{array}$ \\
\hline RB-TP53-RB12-KO & $\begin{array}{l}\text { SCLC } \\
\text { LCNEC }\end{array}$ & Triple homozygous knockout & $\begin{array}{l}R b \\
\text { Tp53 } \\
R b 12\end{array}$ \\
\hline
\end{tabular}

Reference

Zindy et al. (2003)

Powell et al. (1998)

Cho et al. (1999)

Russell et al. (2002)

Vitagliano et al. (2006)

Chakravarty et al.

(2011)

Suzuki et al. (2002)

Pringle et al. (2012)

Ribeiro-Neto et al. (2004)

Yeager et al. (2007), Antico-Arciuch et al. (2010)

Dobson et al. (2011)

Antico Arciuch et al. (2011)

La Perle et al. (2000)

Powell et al. (2001)

Zhu et al. (2014)

Charles et al. (2014)

McFadden et al. $(2014 a, b)$

Michiels et al. (1997)

Acton et al. (2000)

Pozo et al. (2013)

Harvey et al. (1995)

Bland et al. (2000)

Doghman et al. (2007)

Zubair et al. (2009)

Assie et al. (2014)

Heaton et al. (2012)

Weber et al. (1999)

Drelon et al. (2012)

Heaton et al. (2012)

Else et al. (2009)

Mellon et al. (1994)

Sahut-Barnola et al. (2000)

Meuwissen et al.

(2003)

Schaffer et al. (2010) 
Table 2 Continued.

\begin{tabular}{l} 
Model name \\
\hline RP-TP53-PTEN-KO \\
CC10-hASH1 \\
GEP-neuroendocrine \\
tumors \\
INS-GAS \\
Gastrin KO \\
RIP-Tag \\
RIP-MyrAkt1 \\
Glu-Tag \\
RIP-Tag/RIPPyST1 \\
ITF-Tag
\end{tabular}

\begin{tabular}{l} 
Tumor type \\
\hline SCLC \\
LCNEC \\
NSCLC \\
SCLC \\
NSCLC
\end{tabular}

Model type
Triple homozygous knockout
Transgenic

\begin{tabular}{l}
\hline Gene (promoter*) \\
\hline$R b$ \\
Tp53 \\
Pten \\
Ascl1 (Scgb11*)
\end{tabular}

Reference

Cui et al. (2014)

NSCLC

Stomach NET

Stomach NET

Transgenic

Homozygous knockout

Pancreatic NET Transgenic

Pancreatic NET

Pancreatic NET

Colon NET

Pancreatic NET

Colon NET

Colon NET
Transgenic

Transgenic

Transgenic

Transgenic
INS-GAS(INS*)

Gast

SV40-Tag (Rat

Insulin-2*)

MyrAkt1 (Rat

Insulin*)

SV40-Tag (Glu*)

Wang et al. (1993)

Friis-Hansen et al. (1998)

Hanahan (1985)

Tuttle et al. (2001),

Alliouachene et al. (2008)

Efrat et al. (1988)

SV40-Tag

(RIPPYST1*)

SV40 (ITF*)
Grant et al. (1991)

Gum et al. (2004) chemo-preventive role of several drugs (i.e. aspirin or enalapril) in the progression of pancreatic neuroendocrine tumors in the context of MEN1 syndrome (Manoharan et al. 2018). However, these heterozygous models have the limitation of the unspecific and uncontrolled tumor appearance (Piret \& Thakker 2011), and thus, currently, the models most commonly used are conditional knockouts, since they represent the most suitable models to study specific pathologies. Specifically, several conditional models have been generated by the knocking down of specific regions of Men1 gene in specific cell types. Among them, the most important mutants are those generated in parathyroid and alpha and beta pancreatic cells. In particular, conditional knockout mice of Men1 in parathyroid gland-produced parathyroid neoplasia and hypercalcemic hyperparathyroidism, which was useful to study their pathological consequences (Libutti et al. 2003). Similarly, pancreatic knockout models of Men1 are particularly important in that they are contributing to generate pivotal advances in these pathologies. For instance, the mouse model wherein Men1 was knocked out in beta cells under the regulation of $P d x 1$ promoter have been used to explore the effectiveness of pasireotide, a somatostatin analog, in the treatment of pancreatic neuroendocrine tumors in the context of MEN1 syndrome (Quinn et al. 2012).

Likewise, MEN2 syndrome is also an autosomal dominantly inherited disorder, which is specially associated to the development of medullary thyroid carcinomas (MTC), pheochromocytomas and parathyroid

(c) 2019 Society for Endocrinology Published by Bioscientifica Ltd.
Printed in Great Britain adenomas (Jimenez \& Gagel 2004). MEN2 syndrome appears by the mutation of RET (rearranged during transfection), which may occur in different regions of the gene, leading to three different MEN2 syndrome subtypes, termed MEN2A, MEN2B and familial MTC (Pacheco 2016, Wiedemann \& Pellegata 2016). Consequently, the mouse models associated to these pathologies have been developed imitating their respective mutations and exhibit remarkable similitudes (Table 1). Specifically, mouse models of MEN2A syndrome (mutation Cys634Arg) have been generated by developing transgenic mice with the expression of MEN2A Cys634Arg under the control of the rat calcitonin/calcitonin gene-related peptide $(C T / C G R P)$ promoter, which led to the appearance of pheochromocytomas, MTCs and parathyroid tumors, and served, for instance, to improve the PET imaging techniques of MTC (Pestourie et al. 2010). Interestingly, PDX models have also been used for the study of this syndrome, wherein cells from a patient with MEN2A syndrome were reprogramed and injected in immunodeficient mice, maintaining their initial characteristics (Hadoux et al. 2016). For MEN2B syndrome, which also develops with the appearance of MTC and pheochromocytomas, mouse models with MEN2B characteristic Ret mutation (Met918Thr) have helped to corroborate molecular aspects of the syndrome, as well as the C-cell hyperplasia or the presence of sympathoadrenal malformations (Smith-Hicks et al. 2000). In the case of familial MTC, there is no mouse model available nowadays, which severely hampers the study of this syndrome (Wiedemann \& Pellegata 2016). 
Another syndrome associated to the appearance of endocrine tumors is the neurofibromatosis type 1 (NF1) syndrome, which is especially linked to the appearance of pheochromocytomas and duodenal neuroendocrine tumors, although parathyroid or other gastroenteropancreatic (GEP) tumors may also occur (Kalkan \& Waguespack 2013). This syndrome is caused by a mutation in the NF1 gene, which encodes the main inhibitor of RAS in the MAPK pathway. The principal murine model for this syndrome is based in the heterozygous mutation of $N f 1$ gene, generated by the deletion of the exon 31, which has been shown to develop pheochromocytomas in adults, while the homozygosity for the mutation of $N f 1$ gene leads to embryonic lethality (Lepoutre-Lussey et al. 2016) (Table 1). This model has been used to provide important information regarding differential mRNA expression in the context of $\mathrm{N} f 1$ mutation, which indicates the possible existence of neural progenitors in pheochromocytomas (Powers et al. 2007).

There are a number of additional syndromes associated to endocrine and neuroendocrine tumors, but the knowledge gathered about them from mouse models is much more limited (Table 1). This is the case of MEN4 syndrome, which is caused by mutations in CDKN1B and is mainly related with the appearance of pituitary and parathyroid tumors (Lee \& Pellegata 2013). Full elimination of this gene causes primarily pituitary tumors and other multiple organ hyperplasia in mice (Fero et al. 1996, Kiyokawa et al. 1996, Nakayama et al. 1996), but there are not yet conditional knockout models available. Thus, murine models of this syndrome are mainly based in heterozygous mutations of $C d k n 1 b$ gene. However, although these heterozygous models have been used to study the role of this gene in tumorigenesis, there are no studies about the context of these mutations in MEN4 syndrome.

Other examples are the VHL and tuberous sclerosis complex syndromes, which are associated with pheochromocytomas, paragangliomas, pancreatic and other neuroendocrine tumors. Complete ablation of genes causing these syndromes in knockout mice is embryonically lethal and, unfortunately, the heterozygous mutations are excessively dependent on the genetic background of the mouse strains. For these reasons, tissueor cell type-specific knockout models are more commonly used (Table 1). This is the case of a mouse model generated by the knocking out of $\mathrm{Vhl}$ gene in neural crest-derived tissues, which resulted in paraganglioma development, and have served to show the relationship between Vhl, Hif1a and the microRNA miR-210 in this disease
(Merlo et al. 2017). Alternatively, VHL syndrome has also been studied using PDX mice in the context of paragangliomas, which led to the demonstration that, in VHL disease, a therapy directed inhibiting the angiogenesis induced by constitutively expressed VEGF may constitute an effective medical treatment (Gross et al. 1999).

\section{Models of pituitary tumors}

Pituitary adenomas (PAs) are generally benign adenomas from a mono/oligoclonal origin, which display heterogeneous clinical manifestations, derived from hormone over-secretion and/or mass effects due to excess growth. PAs are mainly classified depending on the cell type of origin as somatotropinomas, corticotropinomas, prolactinomas, non-functioning PAs and so forth (Melmed 2011). The pathophysiology of PAs seems to be associated to the imbalance of stimulatory and inhibitory signals or key genes regulating the proliferation and secretory function of the main hormonal cell types conforming the pituitary gland, and, therefore, most of the GEM models to study these pathologies have been generated modulating these factors (Table 2 ).

The vast majority ( 90\%) of existing PA GEM models have been established using gene knockout or overexpression methods in mice (Table 2). To date, homologous deletion of ten different genes (Men1, Cdkn1b, Prkar1a, Rb, Cdkn2b (encoding p19), Drd2, Cdkn2c, Aip, $\mathrm{Prl}$ and $\mathrm{Prlr}$ ) have been reported to yield mouse-knockout models for pituitary tumors. Of these ten genes, Men1, $C d k n 1 b$, Prkar1a, Cdkn2b and Aip are tumor suppressors associated with human familial disorders that course with pituitary tumors. Indeed, Men1-knockout models described above develop PAs among other endocrine and neuroendocrine tumors (Crabtree et al. 2001, 2003, Biondi et al. 2002, 2004, Bertolino et al. 2003, Loffler et al . $2007 a, b)$. In conventional heterozygous Men 1 models, PAs occurred in $26-45 \%$ of mice by 18 months of age, with prolactinomas being the most common type, whereas, in conditional homozygous, the incidence rises up to 58\% of mice (Crabtree et al. 2003). In addition, $C d k n 1 b^{+/-}$and Prkar1a+/- GEM models develop tumors consistent with MEN4 and Carney Complex syndromes, respectively. These mice are characterized by the presence of PAs (e.g. somatotropinomas) in association with other endocrine tumors (e.g. adrenal tumors and follicular thyroid adenomas) (Kiyokawa et al. 1996, Nakayama et al. 1996, Fero et al. 1998, Yin et al. 2008). In addition, Cdkn2c and Aip knockout resulted in representative acromegaly/ gigantism GEM models. Cdkn2 $c^{+/-}$mice have been shown 
to develop somatotropinomas and exhibit gigantism and widespread organomegaly, in that the pituitary gland, spleen and thymus are disproportionately enlarged and hyperplastic (Franklin et al. 1998). Moreover, the phenotypic features of $\mathrm{Aip}^{+/-}$mice are similar to those observed in familial isolated pituitary adenoma patients who have AIP mutations and predominantly develop GH-secreting adenomas, although some patients may also develop PRL- or ACTH-secreting and non-functioning PAs. Heterozygous mice developed normally but were prone to PAs, in particular to those secreting GH, while no excess of any other tumor type was found. A complete loss of Aip was detected in these lesions, and full penetrance of tumors was reached at the age of 15 months. Ki-67 analysis indicated that Aip-deficient tumors have higher proliferation rates compared with Aip-proficient tumors in mice, which is comparable to that found in human tumors, suggesting a more aggressive disease (Vierimaa et al. 2006, Leontiou et al. 2008, Raitila et al. 2010). These models have been shown to nicely recapitulate the features of human PAs and, for this reason, the latter model has been useful to elucidate the mechanisms causing PAs. Indeed, the Aip-deficient tumors showed a drastic reduction in the expression of aryl hydrocarbon receptor nuclear translocator 1 or 2 (ARNT or ARNT2) protein, which are involved in the regulation of several genes associated with tumorigenesis and hypoxia process, thus suggesting mechanisms of AIP-related tumorigenesis (Raitila et al. 2010).

On the other hand, genes such as $R b, C d k n 2 b$, Drd2, Prl and Prlr have not been previously associated with the prevalence of PAs, but studies in mouse models have revealed roles for such genes in pituitary tumorigenesis. Indeed, the absence of $\mathrm{Rb}$ protein caused by heterozygous germline mutation induces childhoodonset retinoblastoma in a high percentage of humans. Surprisingly, the same phenomenon in mice induced the development of pituitary carcinomas (Jacks et al. 1992, Vooijs et al. 1998, 2002). Similarly, the role of p19, encoded by $C d k n 2 b$, as a tumor suppressor in regulating pituitary anterior lobe proliferation has been revealed by a conventional knockout mouse model of $C d k n 2 b$, as these knockout mice developed multiple tumor types including PRL-, GH- and FSH-secreting PAs (Bai et al. 2014).

As mentioned above, the transgenic overexpression of the main regulators of pituitary gland function has also been used to generate key GEM models of PAs (Table 2). This is the case of overexpression of the growth hormone releasing hormone (Ghrh) gene, which resulted in PAs that led to excessive GH secretion (Asa et al. 1992).
These mice exhibited adenomas with variable ultrastructural appearances, ranging from cells that resembled somatotropes or mammosomatotropes to cells with features of the glycoprotein hormone cell line and have been useful to identify mechanisms that may prevent or delay adenoma formation in the presence of excess GHRH (Luque et al. 2009). Similarly, transgenic overexpression of corticotropin-releasing hormone (Crh) or N-ethyl-Nnitrosourea-induced mouse mutant with a $\mathrm{Crh}$ promoter mutation have also been generated as models of Cushing's disease (Stenzel-Poore et al. 1992, Bentley et al. 2014). In particular, Crh-transgenic animals exhibit endocrine abnormalities involving the hypothalamic-pituitaryadrenal axis, including elevated plasma levels of ACTH and glucocorticoids and display physical changes similar to those of patients with Cushing's syndrome, such as excessive fat accumulation, muscle atrophy, thin skin and alopecia. These findings indicate that chronic production of excessive CRF results in sustained stimulation of pituitary corticotrope cells, resulting in elevated ACTH and consequent glucocorticoid overproduction, a condition that leads to the development of Cushing's syndrome. A similar approach based on the modulation of the main regulators of pituitary gland function was implemented with pituitary tumor promoting genes as the pituitary transforming gene (Pttg) or the Hmga genes. Pttg, which was first identified from rat pituitary tumor cells (Pei \& Melmed 1997), and subsequently shown to be overexpressed in human pituitary tumors (Saez et al. 1999), encodes a securing protein that plays a role in cell transformation, aneuploidy, apoptosis and tumor microenvironment communication (Vlotides et al. 2007). Mice with targeted pituitary Pttg overexpression driven by the pituitary specific alpha subunit glycoprotein promoter have been reported to develop focal pituitary hyperplasia, while mice with Pttg inactivation have pituitary hypoplasia (Donangelo et al. 2006), consistent with a pituitary tumorigenic role of Pttg (Abbud et al. 2005, Donangelo et al. 2006). Hmga1 or Hmga2 transgenic mice have also been shown to develop mixed somatotrope/ lactotrope PAs by 16 months of age (Fedele et al. 2002, 2005). In particular, Hmga2 has been related to E2f1 activity with the progression and development of PAs in these models (Fedele et al. 2006).

In addition, five double-mutant models derived from $R b$-knockout mice have been reported hitherto

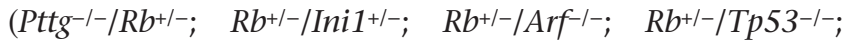
Men $\left.1^{+-} / R b^{+-}\right)$, which have served to explore the interactions between $R b$ and other genes important in PA tumorigenesis (Harvey et al. 1995, Tsai et al. 2002, 
Chesnokova et al. 2005, Donangelo et al. 2006, Guidi et al. 2006, Loffler et al. 2007a,b). Other double mutants as Cdk4R/R/Cdkn1b; Ccne1/p27-/-; p18-/-/p27-/-; p18-/-/aSU---; Ink4c/Arf and Men1 $1^{+/-} / C d k n 2^{-/-}$have also allowed to investigate cyclin-dependent kinases (CDK) inhibitors (CKIs) and their links with CDKs, CKIs and their downstream pathway elements in this pathology (Franklin et al. 1998, Lloyd et al. 2002, Zindy et al. 2003, Sotillo et al. 2005, Roussel-Gervais et al. 2010).

Other methodological alternatives to induce GEM models of PAs include the use of viral particles (oncoviruses) and knock-in approaches (Table 2). Indeed, simian virus 40 (SV40) T antigen (SV40-Tag) is an oncovirus able to generate a mouse model with somatotropinomas when expressed under the control of bovine arginine vasopressin (AVP) gene promoter (Stefaneanu et al. 1992). In addition, mice harboring a SV40-Tag transgene under the control of Pomc promoter developed melanotroph tumors (Low et al. 1993). In the same way, SV40-Tag under the control of the $F s h b$ promoter provided a model of non-functioning adenomas (Kumar et al. 1998). Likewise, the overexpression of the polyoma large $\mathrm{T}$ antigen linked to the polyoma early region promoter generated another model for Cushing's disease (Helseth et al. 1992).

In the case of PAs, the absence of established commercial cell lines from human PAs profoundly hampers the possibility of generating human CDXs. However, commercial murine cell lines such as AtT-20, GH3, GH4-C1 and non-commercial human cell lines have been used to date. For instance, AtT-20 and GH3 xenograft mice have been used in different studies to explore the sensibility or sensitizing effect to current treatments, chemotherapeutics drugs and radiotherapy in PAs (Zeng et al. 2011, Dai et al. 2013, Li et al. 2014, Lin et al. 2015, Zhao et al. 2015). Indeed, in recent years, mice xenografts have been widely used to characterize the responses to drugs currently prescribed for these pathologies as lanreotide (Ning et al. 2009), thiazolidinediones (Mannelli et al. 2010), bromocriptine and/or cabergoline (Lin et al. 2017) or to alternative therapies such as metformin (An et al. 2017), histone deacetylase inhibitor SAHA (Lu et al. 2017), Liquiritigenin (Wang et al. 2014), Triptolide (Li et al. 2017) or Bafilomycin A1 (McSheehy et al. 2003), which have been shown to exhibit antitumoral roles in these pathologies. Likewise, PAs xenograft models have also been used to characterize the function of different pathways, genes and relevant mutations in several types of PAs, as Fgfr4 in intracranial xenograft mouse models (Ezzat et al. 2006, Jalali et al. 2016), inactivating mutations of Pit-1 (Roche et al. 2012), overexpression of Lrig1 (Cheng et al. 2016) or Meg3 (Chunharojrith et al. 2015), persistent activation of the Ras/MAPK pathway (Booth et al. 2014), antitumoral actions of miR-524-5p (Zhen et al. 2017) and role of RSUME in PTTG protein stabilization (Fuertes et al. 2018). Finally, PDX models have been sparsely implemented in the case of PAs. However, a recent study has described the appropriate methodological approach to generate PDX models through the inoculation of CD15+ pituitary adenoma-initiating cells in humanmouse xenografts, which are capable of inducing tumor initiation (Manoranjan et al. 2016), and, therefore, providing a novel research line in the field of PAs.

\section{Models of thyroid tumors}

Thyroid cancer represents the most common endocrine tumor pathology and comprises different types of tumors, which are classified depending on the cells of origin. Specifically, epithelial thyroid cancers or nonMTC (NMTC) defines those thyroid cancers that arise from thyrocytes, comprising 95\% of all the cases. NMTC tumors are subdivided in papillary (80\%), follicular (10\%) and anaplastic (5\%) subtypes, based on their histological characteristics. On the other hand, the oncogenic dedifferentiation of c-cells originates MTC, which account for about $5 \%$ of all thyroid cancers. Thyroid cancers usually exhibit a slow growth rate and a good prognosis, being anaplastic the most aggressive subtype. However, it should be noted that if any tumor subtype reaches a metastatic stage, the prognosis of the patient worsens dramatically. According to the variety and complexity of this type of tumors, the mouse models of thyroid cancers available today are multiple and diverse, including GEM (Table 2), CDX and PDX models.

In the case of the papillary thyroid carcinomas (PTCs), the most abundant type of thyroid cancer, the vast majority of GEM models have been generated by thyroidspecific transgenic inclusion of a gene critical for the development and/or progression of PTC under the control of the thyroglobulin (TG) promoter, such as the RET-PTC1, RET-PTC3 or TRK-T1 models (Cho et al. 1999, Powell et al. 1998, Russell et al. 2000) or by the transgenic expression of a mutation-activated variant of different oncogenes, such as NRas ${ }^{\text {Lys61Glu }}$ or BRafVal60oGln, under the control of the $T G$ promoter (Vitagliano et al. 2006, Chakravarty et al. 2011) (Table 2). Among them, the tumors originated in the BRaf Val600Gln and RET-PTC3 models are the most similar to human PTCs from a histological perspective, since these tumors exhibit nuclear features and the 'papillae' structures characterizing PTC, respectively (Powell et al. 1998, 
Charles et al. 2011). In addition, the NRas Lys61Glu or BRafVal600Gln mouse models are able to generate invasive PTC tumors (Vitagliano et al. 2006, Chakravarty et al. 2011), although none of them can produce metastasis. However, it should be mentioned that Powell et al. reported a 33\% of advanced-age RET-PTC3 mice with metastatic lesions (Powell et al. 1998). Remarkably, these models are highly translational and representative of the disease, inasmuch as the same BRAFVal600Gln mutation and activating RAS mutations are found in about 60 and 10\% of all human PTCs, respectively (Nikiforova \& Nikiforov 2009, Cancer Genome Atlas Research Network et al. 2014), and the RTK rearrangement represents the second most common genetic dysregulation in human PTC tumors (Nikiforova \& Nikiforov 2009). Indeed, these models have been used to describe the importance of p27 as regulator of the PTC phenotype by using the TRK-T1 transgenic model (Fedele et al. 2009), while the BRafval600Gln model was crucial to unveil the role of Gs $\alpha$ and $\mathrm{TSH}$ in the oncogenesis and aggressiveness of PTC (Franco et al. 2011). Furthermore, the BRafVal600Gln model has also been used to test the effectiveness of MEK inhibitors (Chakravarty et al. 2011), wherein these studies served as precedents for clinical trials with MEK inhibitors (selumetinib), in which the effectiveness of the drug to decrease tumor volume and increase the radioiodine uptake was demonstrated (Ho et al. 2013).

On the other hand, models of follicular thyroid cancer (FTC) have been mainly generated by knock-in of mutated and inactivated isoform of thyroid hormone receptor $\beta$ (Thrb) (Suzuki et al. 2002), knockout of Prkar1a (Pringle et al. 2012) or by treating the transgenic mice that express the constitutively active variant Rap1b $1 b^{\text {ln } 12 \mathrm{Val}}$ with goitrogens for 1 year (Ribeiro-Neto et al. 2004) (Table 2). Strikingly, although PAX8-PPARG fusion (PPFP) appears in $35 \%$ of FTC cases, mutations of $R A S$ gene in $45 \%$, and mutations in PIK3CA and PTEN in 5\%, none of the models generated by any of these mutated genes are able to produce an evident tumor phenotype (Yeager et al. 2007, Diallo-Krou et al. 2009, Charles et al. 2014, Pringle et al. 2014). Indeed, the results from PTEN models are quite controversial, since some groups have reported that tissue-specific knockout of Pten in the thyroid gland is sufficient to generate metastatic FTC (Antico-Arciuch et al. 2010), while other groups have reported hyperplasia in response to loss of Pten in the thyroid (Yeager et al. 2007, Pringle et al. 2014). For these reasons, double-hit GEM models have also been generated. Among them, Pten knockout into the PPFP model has emerged as an ideal model of aggressive FTC tumors (Dobson et al. 2011). In fact, the Rap1 $b^{\text {Glu12Val }}$, Prkar1a, TR $\beta-P V$ and Pten-PPFP models develop locally invasive FTC tumors, although only the latter two generate distant metastasis (Dobson et al. 2011). Even though these mouse models recapitulate human thyroid cancer features, they exhibit some differences with human FTCs, such as elevated circulating T3 and T4 levels in the case of TR $\beta-P V$ (Kato et al. 2004). In any case, these models have served to provide relevant basic and clinical information regarding the biology of FTCs and, indeed, the TR $\beta-P V$ model has been used in the first preclinical study testing the PI3K inhibitor (LY294002) in FTC, wherein a significant improvement in survival was found (Furuya et al. 2007).

In the case of anaplastic thyroid carcinoma (ATC), it seems that two different genetic hits are necessary to generate appropriate GEM models (Table 2), since the only model developed with a single genetic hit caused severe hypothyroidism (Zhu \& Cheng 2012). This single-hit model is based on the expression of SV40-Tag under the control of $T G$ promoter (Ledent et al. 1991). Conversely, the double-hit models that generate ATC are the result of deleting Pten and inactivating Tp53 (Antico Arciuch et al. 2011), crossing RET-PTC1 or RET-PTC3 mice with Tp53-/mice (La Perle et al. 2000, Powell et al. 2001), crossbreeding TR $\beta-P V$ mice with KasGlu12Asp mice (Zhu et al. 2014) or combining Braf activation with constitutively active Pik3ca (Charles et al. 2014). Among them, the models that better recapitulate APC tumors observed in humans are the Pten/Tp53 GEM mice, since they present features such as pleomorphism, epithelial-mesenchymal transition, aneuploidy, local invasion and metastases (Antico Arciuch et al. 2011), and the Braf/Tp53 GEM mice, which generate micrometastases similar to those observed in human ATC (McFadden et al. 2014b). Indeed, these two GEM models have been used in preclinical studies to demonstrate the effectiveness of the PLK1 inhibitor GSK461364A and the additive antitumor effect of MEK inhibitor and BRAF in APC (McFadden et al. 2014b, Russo et al. 2013).

For the study of MTC, conditional transgenic mice expressing mutated Ret isoforms, such as RetCys634Arg and Ret Met918Thr under the control of calcitonin/calcitonin gene-related peptide (Ct/CGRP) promoter, have been used (Michiels et al. 1997, Acton et al. 2000). Moreover, the transgenic overexpression of P25 cell cycle regulator under the control of enolase promoter, in response to doxycycline, also generates strongly invasive and metastatic MTC (Pozo et al. 2013). Finally, it should be mentioned that the genetic double hit of heterozygous mutation of Tp53 added to heterozygous mutation of $R b 1$ induces the production of MTC (Harvey et al. 1995). 
Apart from the GEM models, CDX and PDX models have also been used to study different aspects of thyroid cancer pathophysiology. Indeed, several thyroid cancerderived cell lines have been shown to be able to generate tumors in SCID mice, such as FTC-133, FTC-236, THJ-11T, TT or CAL-62, among others. In general, these thyroid cancer-derived CDX models have been commonly used for the study of new therapeutic strategies (Lee et al. 2018, Lin et al. 2018, Lombardo et al. 2018) or to describe the role of specific genes on tumor development and progression (Kim et al. 2014, Lou et al. 2018, Ma et al. 2018). Finally, it should be noted that establishing PDX models of thyroid cancer is, unfortunately, particularly problematic and laborious, mainly due to the slow growth rate of these tumors. The first PDX model of thyroid cancer was generated by Gyory et al. in 2005, and these models have been later used to unveil mechanistic aspects and to identify diagnostic markers of these tumor types (Gyory et al. 2005, Chen et al. 2017).

\section{Models of adrenal gland tumors}

Adrenal gland neoplasms are commonly diagnosed as incidental endocrine findings, being the incidence of these adrenocortical tumors (ACTs) relatively high (Siegel et al. 2018). In addition to benign adrenocortical adenomas (ACAs), malignant carcinomas may also arise in the adrenal cortex, being these adrenocortical carcinomas (ACCs) highly aggressive and routinely fatal. Given the prevalence and severity of ACAs and ACCs, respectively, the treatment and management of adrenal gland tumors remain a significant public health challenge. In that sense, murine models have become essential for the study of this pathology (Table 2).

Different GEM models have been generated and characterized in order to further explore the role of certain molecular factors that are involved in the development and progression of ACTs, including steroidogenic factor-1 (SF1/NR5A1), WNT and $\beta$-catenin (CTNNB) or TP53 (Table 2). In the case of $S F 1 / N R 5 A 1$, the gene dosage is especially critical for its function, as demonstrated by the fact that $\mathrm{Nr} 5 \mathrm{a} 1^{+/}$mice present smaller adrenal glands (Bland et al. 2000). In this sense, a GEM model of increased Nr5a1 expression has been generated by the use of a 500$\mathrm{kb}$ yeast artificial chromosome (YAC) containing the rat Nr5a1 gene (Doghman et al. 2007). The Nr5a1 transgenic model, termed YAC-TR mice, developed ACTs that first appeared as nodular hyperplasia and subsequently progressed to tumors with complete penetrance. Similarly, one model that is closely related to the pediatric ACTs is the FAdE-SF1 transgenic mice, which express multiple copies of a transgene engineered to express $\mathrm{Nr} 5 \mathrm{a} 1 \mathrm{using}$ a fetal enhancer (Zubair et al. 2009). These mice had larger adrenal glands as well as ectopic adrenal tissue in the thorax, but did not develop adrenal tumors. In all cases, these Nr5a1 mouse models have been used to further explore the role of this crucial factor in the development of ACTs, particularly in childhood ACTs, as $90 \%$ of cases display gains of $9 \mathrm{q}$, which is the chromosomal region containing NR5A1 gene (Figueiredo et al. 2005)

The modulation of the classical $\mathrm{WNT} / \beta$-catenin or associated pathways has also been used for the generation of different GEM models of ACTs and to explore the implication of these pathways in their development and progression (Table 2). First, 0.5 Akr1b7-Cre mice, which express Cre recombinase in all steroidogenic cells of the adrenal cortex (Lambert-Langlais et al. 2009), were crossed with Catnb ${ }^{\operatorname{lox}(\mathrm{ex} 3)}$ mice (Harada et al. 1999). Histological analysis of these mice, termed $\Delta$ Cat mice, showed severe defects in adrenal architecture with progressive dysplasia and hyperplasia. Second, ectopic Wnt activation in the adrenal cortex has been implemented through conditional loss of $A p c$, an upstream inhibitor of the Wnt pathway, similar to that observed clinically in some sporadic ACC patients (Assie et al. 2014). To this end, mice harboring an $A p c$ allele floxed at exon 14 (Apcloxp/loxp) were crossed with mice expressing the Sf1-Cre transgene (Heaton et al. 2012). Particularly, a stochastic Sf1-Cre driver was used, resulting in Cre-mediated recombination in a subset of adrenocortical cells (Bingham et al. 2006). In any case, both models have been used to demonstrate that exacerbated WNT/ $\beta$-catenin signaling in cells of the adrenal cortex is associated with surprisingly low penetrance of adrenal tumors, which displayed slow progression. Remarkably, the WNT/ $\beta$-catenin signaling has been shown to interact with insulin-like growth factor 2 (IGF2), which has also been thought to be associated with adrenal tumorigenesis. Indeed, a possible connection between IGF2 and ACC was first suggested by a familiar cancer susceptibility syndrome, which is characterized by alterations at $11 \mathrm{p} 15$, an imprinted locus where IGF2 gene resides. However, clinical trials in advanced ACC patients have found slight benefit of IGF1R inhibitors (Fassnacht et al. 2015). Consistent with this observation, Igf2 transgenic mice generated using the rat phosphoenolpyruvate carboxykinase (Pepck) promoter presented elevated Igf2 serum levels and hyperplastic growth leading to increased overall adrenal weight, but adrenal tumors were not seen in animals up to 18 months of age (Weber et al. 1999). In addition, Igf2 overexpression 
in the adrenal cortex using regulatory regions from the $A k r 1 b 7$ gene in the so-called AdIgf 2 mice resulted in almost seven-fold higher basal levels of Igf2 and increased infiltration of mesenchymal cells in the adrenal cortex but again no tumor development (Drelon et al. 2012). Altogether, these GEM models have served to suggest that the single alteration of WNT/ $\beta$-catenin or IGF2 pathways is not sufficient to drive adrenal cortex tumor formation. Nevertheless, these observations led to propose a model of cooperation between the WNT pathway and IGF2, which was tested in two independent mouse models. First, mice were generated with joint loss of $A p c$ and overexpression of $I g f 2$, by mating the Apc-knockout and $H 19 \triangle D M D$ mice (Heaton et al. 2012). This resulted in a more aggressive tumor phenotype, marked by earlier onset of tumor formation, a higher tumor penetrance and formation of one overt carcinoma. A second model combining the described $\triangle$ Cat and AdIgf2 mice confirmed these results and also found a higher tumor Weiss score (the most commonly used method for assessing malignancy of ACTs) when both pathway alterations were present (Drelon et al. 2012).

Mutations in TP53 exhibit a high prevalence in ACC; however, no direct GEM models of adrenal restricted TP53 loss have been developed to date. Nonetheless, there are several GEM models that indirectly study the functional consequences of TP53 loss during adrenal tumorigenesis. The first approach is based on the crossbreeding of the Acd mouse, which contains a spontaneous, recessively hereditary mutation in the adrenocortical dysplasia $(A c d)$ gene that results in adrenal insufficiency (Beamer et al. 1994), with mice from a Tp53-null background (Else et al. 2009). This results in a significant increase in carcinoma formation, including ACC in 5\% of animals, suggesting that the adrenal hypoplasia seen in Acd mice results from Tp53-dependent senescence and apoptosis and that release from Tp53-sensitive checkpoints is a critical step in the adrenal tumorigenesis. In addition, two transgenic lines expressing SV40-Tag, which acts in part by binding and inactivating Tp53, in the adrenal cortex have been generated. In these models, the promoter of the human P450 cholesterol side-chain cleavage gene (Mellon et al. 1994 ) or a $0.5 \mathrm{~kb}$ region of the $A k r 1 b 7$ promoter (SahutBarnola et al. 2000) were used to express an SV40-Tag construct. This approach resulted in the generation of ACTs that were subsequently used to generate ACTHresponsive cell lines (ATC1 and ATC7-L) (Sahut-Barnola et al. 2000).

In addition to the GEM models, different CDX and PDX models have been used to investigate different aspects of ACT pathophysiology. Among them, the most commonly used are the CDX models obtained from the inoculation of the human ACC cell line NCI-H295 (Logie et al. 2000). These mice exhibit elevated plasma steroid levels as well as an overexpression of $I g f 2$ and Igf-binding protein 2 (Igfbp2). Moreover, a significant inhibition of tumor growth and increase in survival time could be observed after treatment with IGF1R antagonistic compounds (Hantel et al. 2012). Similar preclinical ACC model has been generated by the subcutaneous injection of SW13 cells. These models have served to provide the first evidence regarding the usefulness of local gene transfer therapy of an HSV thymidine kinase expressing adenoviral shuttle followed by ganciclovir treatment (Wolkersdorfer et al. 2002), to investigate the antitumor efficacy of different drugs such as sorafenib and everolimus (Mariniello et al. 2012) or to facilitate the enrichment of cancer stem cells from this tumor model (Zeng et al. 2014). Finally, PDX models of ACT have also been generated. Specifically, Pinto et al. reported in 2013 the establishment of the first pediatric tumor model for ACC. In this case, the original patient tumor derived from an 11-year-old boy with an incidentally found right adrenal mass resected and subsequently confirmed as an ACC (Pinto et al. 2013). For inoculation of tumor xenografts, surgical specimens were implanted as tumor pieces without mincing in CB17 $\mathrm{scid}^{-/-}$mice (SJACC3). Similarly, Hantel et al. in 2014 used female athymic NMRI $\mathrm{nu} / \mathrm{nu}$ mice to successfully generate NCIh295 cell line xenografts and PDXs to test different treatment regimens, which indicates that these xenografts could be utilized as standardizable tumor model for multiple preclinical settings (Hantel et al. 2014).

\section{Models of neuroendocrine tumors}

\section{GEP-neuroendocrine tumors}

GEP-neuroendocrine tumors (GEP-NETs) are the most common type of neuroendocrine tumor and have been classified by the World Health Organization into three categories (G1, G2 and G3) based on tumor size, histopathological differentiation, proliferation index (Ki-67), hormonal behavior, neuroendocrine biomarkers (such as serotonin and chromogranin A), direct invasion and distant metastasis (Oberg 2018). GEP-NETs comprise a heterogeneous group of rare neoplasias with increasing incidence and prevalence that arise in almost all regions of the GEP tract, although some of them are not very frequent or are associated to the existence of specific syndromes (e.g. MEN1). For this reason, although 
the development of GEM models for certain types of GEP-NETs is quite limited, in general terms, there are a wide variety of GEP-NETs GEM models (Capdevila et al. 2017) (Table 2).

The stomach may be the origin of different types of GEP-NETs, which represent about 7-8\% of the total (Yang et al. 2018b). The most common of these tumors are related with an abnormal production of gastrin, which could be linked with a chronic $H$. pylori infection. One of the most typical stomach GEP-NET models is the insulin-gastrin (INS-GAS) mouse, which overexpresses the human gastrin gene under the control of the mouse insulin promoter (Wang et al. 1993). These mice exhibit elevated serum levels of human amidated gastrin and spontaneously develop gastric atrophy, metaplasia, dysplasia and eventually progress to invasive gastric tumors in the corpus by 20 months of age without lymph node invasion or distant metastasis. Because of this, it is considered a valuable model of stomach GEP-NET development in combination with other agents, like $H$. pylori or $H$. felis. Strikingly, the genetic ablation of gastrin in the gastrin-deficient mice (Friis-Hansen et al. 1998) also results in the development of spontaneous gastric cancer at few weeks of age (Friis-Hansen 2002), suggesting that any dysregulations of gastrin production may lead to oncogenic growth.

In the case of pancreatic neuroendocrine tumors (panNETs), the first GEM model reproducing this pathology, the so-called RIP-Tag model, was generated in 1985 (Hanahan 1985). Due to the exclusivity of the pancreatic $\beta$-cells to synthesize insulin hormone, the authors used the promoter of the insulin gene (Rat Insulin-2 (RIP)) to mediate the expression of the SV40Tag oncogene (Table 2). This model results in an invasive carcinoma that nicely recapitulates some of the typical panNETs characteristics, including $\beta$-cell hyperplasia, dysplasia and angiogenesis. The RIP-Tag mouse model is considered a valuable model of panNETs development, and it has been used in numerous preclinical studies to test the potential therapeutic effects of several drugs (Casanovas et al. 2005, Chiu et al. 2010). Furthermore, Hanahan et al. described the role of different promoters to induce the overexpression of the SV40-Tag and, among them, the most commonly used GEM models derived from the RIP-Tag have been RIP1-Tag2 and RIP1-Tag5 (Onrust et al. 1996), which are used as models of angiogenesis and immune response to tumorigenesis, respectively. After this, several groups followed the strategy of the RIP method, to study different panNETs characteristics (Table 2). One of these is the RIP-MyrAkt1 mouse model, which develops a moderate insulinoma and has been used to explore the role of Akt in the $\beta$-cell activation. This model demonstrated that Akt1 is a key regulator of pancreatic $\beta$-cell functions, for these mice developed $\beta$-cell hyperplasia and dysplasia, which progress to insulinomas in older mice (Tuttle et al. 2001, Alliouachene et al. 2008).

Using a similar approach, in 1988, a new model for glucagonomas was published (Table 2). In this case, the SV40-Tag was overexpressed under the control of the glucagon promoter $(G l u)$, so that it was exclusively expressed in pancreatic $\alpha$-cells (Efrat et al. 1988). Curiously, despite the fact that it could be possible to find expression of Glu-Tag in the central nervous system, it only had the capacity of establish glucagonomas. The hyperplasia of $\alpha$-cells in Langerhans islets led to the formation of solid tumors in 9-12 months-old mice, which showed several similarities with sporadic human glucagonomas (Rindi et al. 1991). Subsequently, a Glu-Tag mouse model with a more aggressive tumor was also described, but it was not a specific model as they also presented poorly differentiate intestinal neuroendocrine tumors (Lee et al. 1992). In contrast to insulinomas and glucagonomas, there are no well-established GEM models for the study of somatostatinomas.

Although intestine neuroendocrine tumors are one of the most incident GEP-NETs, there are not many GEM models that resemble this group of pathologies, except for colon neuroendocrine tumors (Table 2). Although colon adenocarcinoma is the pathology that more predominantly affects this organ, colon neuroendocrine tumors have also been described and, in this sense, it is worth noticing that the previously described models Glu-Tag and a version of RIP-Tag mice, the RIP-Tag/RIPPyST1, also develop colon neuroendocrine tumors in addition to panNETs. These intestinal tumors, which first appear in submucosal areas, metastasize with high frequency to the lymph nodes and liver. In these mice, preneoplastic mucosal lesions were not observed, indicating that invasiveness is acquired early in the tumorigenic progression of these cells (Grant et al. 1991). Additionally, using a more precise approach, the ITF-Tag mouse model was generated by expressing the SV40-Tag under the control of the intestinal trefoil factor $(I T F)$ promoter, which led to the generation of a colon neuroendocrine tumors model. This caused tumor formation in the proximal colon with remarkable efficiency (multifocal and invasive tumors) (Gum et al. 2004).

Finally, there are different CDX and PDX models of GEP-NETs that could complement the GEM models described earlier. In the case of CDXs, the development of 
an esophagus neuroendocrine carcinoma (NEC) cell line, NEC-DUE (Krieg et al. 2014), and a glucagonoma cell line, GLU-Tag cells (Drucker et al. 1994), provided new tools to design and generate preclinical models, based on the initial evidence that establishment of xenografts revealed their validity as model of these rare pathologies. In the case of somatostatinomas, although different studies have isolated cells from different mouse models that develop this type of pathology, like the $\mathrm{Tg}$ (Ela-1-SV40E)Bri18 mice (Pettengill et al. 1994), the most commonly used models are CDXs with specific cell lines, such as the QGP-1 human panNET cell line (Fraedrich et al. 2012). Furthermore, CDXs developed with some cell lines derived from intestinal neuroendocrine tumors (ileum or rectum), such as KRJ-I or GOT1, have been used to explore the role of different drugs in these pathologies as the response in CDXs has been found to be consistent with the clinical response (Pfragner et al. 1996, Kolby et al. 2001, Nilsson et al. 2004, Stilling et al. 2007). In contrast, the establishment of relevant GEP-NET PDX models has been historically highly problematic (Tanaka et al. 1999, Yang et al. 2016). Nevertheless, some authors have reported the generation of a GEP-NET PDX collection from 106 patients' tumors (Tanaka et al. 1999, Yang et al. 2016) or the generation of a gastric NEC PDX model, GA0087, which was used to successfully validate the extended survival rate in response to cisplatin relative to untreated controls, which is concordant with clinical results (Jiang et al. 2015).

\section{Pulmonary neuroendocrine tumors}

Pulmonary neuroendocrine tumors arise from either individual or clusters of neuroendocrine cells that reside in the lung and often display an active secretory phenotype. They comprise the second most common type of neuroendocrine tumors, accounting for $25 \%$ of primary lung tumors. These tumors can be subdivided in four types, depending on their histology, and in three groups, regarding their grade: low-grade or typical carcinoids, intermediate-grade or atypical carcinoids and two high-grade tumors, large cell neuroendocrine carcinoma (LCNEC) and SCLC (Dincer et al. 2015). In this review, we will mainly focus on high-grade tumors, although the few mouse models available for typical or atypical tumors will be briefly commented (Table 2).

In terms of the high-grade SCLCs and LCNECs, due to the fact that they are rarely resected, material from human source is very limited. Therefore, translational research of these pathologies is mainly based in GEM models, which represent an essential tool in this field (Gazdar et al. 2015). These tumors are strongly associated with smoking habits and are characterized by high proliferation and mitotic rates, as well as other aggressiveness-related features. In addition, the development of these tumors is closely related to the inactivation of TP53 and RB1 genes (Gazdar et al. 2017, Pelosi et al. 2017). For this reason, all the GEM models used for the study of high-grade pulmonary neuroendocrine tumors are based in adenoviruses-based conditional $R b 1$ and/or Tp53 double knockout, which have been combined with other knockout models (Gazdar et al. 2015). The first model developed was the Rb1/Tp53 double knockout, which develops both types of highgrade pulmonary neuroendocrine tumors, being the SCLC the most predominant (Meuwissen et al. 2003). However, due to the extended latency of these tumors, the first triple knockout was developed seven years later, which included the Rbl2 mutation (p130 protein). Interestingly, these mice displayed a shorter latency time and presented LCNEC first and SCLC later, which could progress to metastases (Schaffer et al. 2010). These models have been shown to closely recapitulate the typical features of highgrade pulmonary neuroendocrine tumors in human and have been used in the study of the genomic landscape of SCLCs (George et al. 2015), in the identification of the tumorigenic population of SCLC (Jahchan et al. 2016) or to demonstrate the existence of distinct metastatic programs attributable to the cell type of origin (Yang et al. 2018a).

Subsequently, additional Rb1/Tp53/Pten tripleknockout models have been generated by the use of different experimental approaches, but in all cases, the pathology of these new models was considerably more complex than the previous models (Table 2). Indeed, these mice developed the tumors and died faster than the previous, but the non-endocrine component of the tumors was also higher, which could be associated to the modification of the driver promoter. These tumors exhibited LCNEC, SCLC and non-SCLC components, with more SCLC constituents in metastases (Cui et al. 2014, McFadden et al. 2014a). Moreover, additional GEM model of pulmonary neuroendocrine tumors have been generated with different genetic modifications. In this case, the co-expression of SV40-Tag and Ascl1 under the constitutive Scgb1a1 promoter generated a model that developed adenocarcinoma with neuroendocrine characteristics and neuroendocrine differentiation in tumors (Linnoila et al. 2000).

In addition to these GEM models, other pulmonary neuroendocrine tumor models based on CDX and PDX approaches have been described in several studies. Indeed, different SCLC-derived cell lines have been used in CDX 
models to explore different aspects of SCLC biology. For instance, xenografted NCI-H510A cell line has been used to investigate LSD1 inhibitors as therapeutic strategy (Takagi et al. 2017) or to study the role of miR-450 in the progression of SCLC (Liu et al. 2016). As well, the SCLC cell lines NCI-H146 and NCI-H446 have been used in CDX models to test new therapies (Zhang et al. 2013, Kloos et al. 2015) and xenografted NCI-H1688 cells have been useful in the search of new therapeutic targets for SCLC, as NOTCH1 (Wael et al. 2014). Interestingly, and despite the very limited human material, there are several studies using PDX mice of SCLC. The importance and fidelity of PDX in SCLC has been very recently reported (Drapkin et al. 2018) and, few years ago, Gao et al. used more than 1000 samples from human tumors, including more than 50 from lung cancer, for PDX models, in order to predict drug response in several pathologies, demonstrating that these models are more accurate than CDX (Gao et al. 2015). In fact, these models have been used to evaluate new therapies, as is the case of PARP inhibitors (Lok et al. 2017), DLL3-antibody (Saunders et al. 2015) or the confirmation in a phase II clinical trial with arsenic trioxide (Owonikoko et al. 2016). In the case of LCNECs, the studies with xenograft models are less numerous and, often, are simultaneous to those of SCLC, such as the DLL3-antibody based study, mentioned above. However, the LCNECs-derived cell line NCI-H810 has also been used in CDX models in order to find novel therapeutic targets, such as TRKB (Odate et al. 2013).

Finally, it is worth noting that there are several works using mouse models for the study of low-grade pulmonary neuroendocrine tumors (Table 2). In two different studies, xenografted mice with NCI-H727 typical tumors cell line were used to explore the role of carbonic anhydrase in these tumors (Mokhtari et al. 2013, Zhou et al. 2015). This cell line, the most used for the study of typical pulmonary neuroendocrine tumors, has been also xenografted for the screening of everolimus effect (Johnbeck et al. 2014), to compare different image techniques (Oxboel et al. 2014), to evaluate the role of certain viruses (Randle et al. 2013) or radiolabeled peptides treatments (Petersen et al. 2012, $\mathrm{Wu}$ et al. 2013) or even to test new isotopes, such as neodinium-140 (Severin et al. 2017).

\section{Conclusions}

Endocrine and neuroendocrine tumors represent a highly heterogeneous group of neoplasms arising from endocrine and neuroendocrine cells that exhibit a limited incidence. For these reasons, the comprehensive study of the molecular and genetic alterations underlying their development and progression represents a highly elusive task and hinders the discovery of novel biomarkers and therapeutic options. In this scenario, this review reveals that mouse models represent powerful and indispensable tools in basic and translational studies exploring the biology of endocrine and neuroendocrine tumors. Indeed, there is a growing wealth of endocrine and neuroendocrine tumors mouse model systems that continuously expand the toolbox for cancer research. Among them, the CDXs comprise, hitherto, the most commonly used models, but the PDX and GEM models provide the best representation of tumor microenvironments, physiological responses and disease pathology. In addition, GEMs further allow for evaluation of immune system interventions and of responses to in situ developed diseases. Therefore, the use of this ample variety of available mouse models, together with the continuous efforts to improve them or to develop new, more sophisticated and valuable models, will drive preclinical studies to a new level of cancer research in the field of endocrine and neuroendocrine tumors.

\section{Declaration of interest}

The authors declare that there is no conflict of interest that could be perceived as prejudicing the impartiality of the research reported.

\section{Funding}

This work was supported by the following grants: Junta de Andalucía (CTS-1406, BIO-0139), ISCIII-FIS, co-funded by European Union (ERDF/ESF, 'Investing in your future') (PI16/00264, CP15/00156, PI17/02287), MINECO (BFU2016-80360-R and FPU14/04290) and CIBER (an initiative of Instituto de Salud Carlos III, Ministerio de Sanidad, Servicios Sociales e Igualdad, Spain).

\section{References}

Abbud RA, Takumi I, Barker EM, Ren S-G, Chen D-Y, Wawrowsky K \& Melmed S 2005 Early multipotential pituitary focal hyperplasia in the alpha-subunit of glycoprotein hormone-driven pituitary tumor-transforming gene transgenic mice. Molecular Endocrinology 19 1383-1391. (https://doi.org/10.1210/me.2004-0403)

Acton DS, Velthuyzen D, Lips CJ \& Hoppener JW 2000 Multiple endocrine neoplasia type $2 \mathrm{~B}$ mutation in human RET oncogene induces medullary thyroid carcinoma in transgenic mice. Oncogene 19 3121-3125. (https://doi.org/10.1038/sj.onc.1203648)

Alliouachene S, Tuttle RL, Boumard S, Lapointe T, Berissi S, Germain S, Jaubert F, Tosh D, Birnbaum MJ \& Pende M 2008 Constitutively active Akt1 expression in mouse pancreas requires S6 kinase 1 for insulinoma formation. Journal of Clinical Investigation 118 3629-3638. (https://doi.org/10.1172/JCI35237)

An J, Pei X, Zang Z, Zhou Z, Hu J, Zheng X, Zhang Y, He J, Duan L, Shen R, et al. 2017 Metformin inhibits proliferation and growth 
hormone secretion of GH3 pituitary adenoma cells. Oncotarget 8 37538-37549. (https://doi.org/10.18632/oncotarget.16556)

Antico-Arciuch VG, Dima M, Liao XH, Refetoff S \& Di Cristofano A 2010 Cross-talk between PI3K and estrogen in the mouse thyroid predisposes to the development of follicular carcinomas with a higher incidence in females. Oncogene 29 5678-5686. (https://doi. org/10.1038/onc.2010.308)

Antico Arciuch VG, Russo MA, Dima M, Kang KS, Dasrath F, Liao X-H, Refetoff S, Montagna C \& Di Cristofano A 2011 Thyrocyte-specific inactivation of p53 and Pten results in anaplastic thyroid carcinomas faithfully recapitulating human tumors. Oncotarget 2 1109-1126. (https://doi.org/10.18632/oncotarget.380)

Asa SL, Kovacs K, Stefaneanu L, Horvath E, Billestrup N, GonzalezManchon C \& Vale W 1992 Pituitary adenomas in mice transgenic for growth hormone-releasing hormone. Endocrinology 131 2083-2089. (https://doi.org/10.1210/endo.131.5.1425411)

Assie G, Letouze E, Fassnacht M, Jouinot A, Luscap W, Barreau O, Omeiri H, Rodriguez S, Perlemoine K, Rene-Corail F, et al. 2014 Integrated genomic characterization of adrenocortical carcinoma. Nature Genetics 46 607-612. (https://doi.org/10.1038/ng.2953)

Bai F, Chan HL, Smith MD, Kiyokawa H \& Pei X-H 2014 p19Ink4d is a tumor suppressor and controls pituitary anterior lobe cell proliferation. Molecular and Cellular Biology 34 2121-2134. (https:// doi.org/10.1128/MCB.01363-13)

Basham KJ, Hung HA, Lerario AM \& Hammer GD 2016 Mouse models of adrenocortical tumors. Molecular and Cellular Endocrinology 421 82-97. (https://doi.org/10.1016/j.mce.2015.11.031)

Beamer WG, Sweet HO, Bronson RT, Shire JG, Orth DN \& Davisson MT 1994 Adrenocortical dysplasia: a mouse model system for adrenocortical insufficiency. Journal of Endocrinology 141 33-43. (https://doi.org/10.1677/joe.0.1410033)

Bentley L, Esapa CT, Nesbit MA, Head RA, Evans H, Lath D, Scudamore CL, Hough TA, Podrini C, Hannan FM, et al. 2014 An $\mathrm{N}$-ethyl-N-nitrosourea induced corticotropin-releasing hormone promoter mutation provides a mouse model for endogenous glucocorticoid excess. Endocrinology 155 908-922. (https://doi. org/10.1210/en.2013-1247)

Bertolino P, Tong W-M, Herrera PL, Casse H, Zhang CX \& Wang Z-Q 2003 Pancreatic beta-cell-specific ablation of the multiple endocrine neoplasia type 1 (MEN1) gene causes full penetrance of insulinoma development in mice. Cancer Research 63 4836-4841.

Bingham NC, Verma-Kurvari S, Parada LF \& Parker KL 2006 Development of a steroidogenic factor 1/Cre transgenic mouse line. Genesis $\mathbf{4 4}$ 419-424. (https://doi.org/10.1002/dvg.20231)

Biondi C, Gartside M, Tonks I, Paterson C, Hayward NK \& Kay GF 2002 Targeting and conditional inactivation of the murine Men1 locus using the Cre recombinase: loxP system. Genesis 32 150-151. (https:// doi.org/10.1002/gene.10061)

Biondi CA, Gartside MG, Waring P, Loffler KA, Stark MS, Magnuson MA, Kay GF \& Hayward NK 2004 Conditional inactivation of the MEN1 gene leads to pancreatic and pituitary tumorigenesis but does not affect normal development of these tissues. Molecular and Cellular Biology 24 3125-3131. (https://doi.org/10.1128/MCB.24.8.31253131.2004)

Bland ML, Jamieson CA, Akana SF, Bornstein SR, Eisenhofer G, Dallman MF \& Ingraham HA 2000 Haploinsufficiency of steroidogenic factor-1 in mice disrupts adrenal development leading to an impaired stress response. PNAS 97 14488-14493. (https://doi. org/10.1073/pnas.97.26.14488)

Booth A, Trudeau T, Gomez C, Lucia MS \& Gutierrez-Hartmann A 2014 Persistent ERK/MAPK activation promotes lactotrope differentiation and diminishes tumorigenic phenotype. Molecular Endocrinology 28 1999-2011. (https://doi.org/10.1210/me.2014-1168)

Cancer Genome Atlas Research Network, Agrawal N, Akbani R, Aksoy BA, Ally A, Arachchi H, Asa SL, Auman JT, Balasundaram M, Balu S, et al. 2014 Integrated genomic characterization of papillary thyroid carcinoma. Cell 159 676-690. (https://doi.org/10.1016/j. cell.2014.09.050)

Capdevila J, Casanovas O, Salazar R, Castellano D, Segura A, Fuster P, Aller J, Garcia-Carbonero R, Jimenez-Fonseca P, Grande E, et al. 2017 Translational research in neuroendocrine tumors: pitfalls and opportunities. Oncogene 36 1899-1907. (https://doi.org/10.1038/ onc.2016.316)

Casanovas O, Hicklin DJ, Bergers G \& Hanahan D 2005 Drug resistance by evasion of antiangiogenic targeting of VEGF signaling in latestage pancreatic islet tumors. Cancer Cell 8 299-309. (https://doi. org/10.1016/j.ccr.2005.09.005)

Chakravarty D, Santos E, Ryder M, Knauf JA, Liao X-H, West BL, Bollag G, Kolesnick R, Thin TH, Rosen N, et al. 2011 Small-molecule MAPK inhibitors restore radioiodine incorporation in mouse thyroid cancers with conditional BRAF activation. Journal of Clinical Investigation 121 4700-4711. (https://doi.org/10.1172/JCI46382)

Charles R-P, Iezza G, Amendola E, Dankort D \& McMahon M 2011 Mutationally activated BRAF(V600E) elicits papillary thyroid cancer in the adult mouse. Cancer Research 71 3863-3871. (https://doi. org/10.1158/0008-5472.CAN-10-4463)

Charles R-P, Silva J, Iezza G, Phillips WA \& McMahon M 2014 Activating BRAF and PIK3CA mutations cooperate to promote anaplastic thyroid carcinogenesis. Molecular Cancer Research 12 979-986. (https://doi. org/10.1158/1541-7786.MCR-14-0158-T)

Chen X, Zhu H, Huang X, Wang P, Zhang F, Li W, Chen G \& Chen B 2017 Novel iodinated gold nanoclusters for precise diagnosis of thyroid cancer. Nanoscale 9 2219-2231. (https://doi.org/10.1039/C6NR07656D)

Cheng S-Q, Fan H-Y, Xu X, Gao W-W, Lv S-G, Ye M-H, Wu M-J, Shen X-L, Cheng Z-J, Zhu X-G, et al. 2016 Over-expression of LRIG1 suppresses biological function of pituitary adenoma via attenuation of PI3K/AKT and Ras/Raf/ERK pathways in vivo and in vitro. Journal of Huazhong University of Science and Technology: Medical Sciences 36 558-563. (https://doi.org/10.1007/s11596-016-1625-4)

Chesnokova V, Kovacs K, Castro AV, Zonis S \& Melmed S 2005 Pituitary hypoplasia in Pttg-/- mice is protective for $\mathrm{Rb}+/$ - pituitary tumorigenesis. Molecular Endocrinology 19 2371-2379. (https://doi. org/10.1210/me.2005-0137)

Chiu CW, Nozawa H \& Hanahan D 2010 Survival benefit with proapoptotic molecular and pathologic responses from dual targeting of mammalian target of rapamycin and epidermal growth factor receptor in a preclinical model of pancreatic neuroendocrine carcinogenesis. Journal of Clinical Oncology 28 4425-4433. (https://doi. org/10.1200/JCO.2010.28.0198)

Cho JY, Sagartz JE, Capen CC, Mazzaferri EL \& Jhiang SM 1999 Early cellular abnormalities induced by RET/PTC1 oncogene in thyroidtargeted transgenic mice. Oncogene 18 3659-3665. (https://doi. org/10.1038/sj.onc.1202709)

Chu X, Gao X, Jansson L, Quach M, Skogseid B \& Barbu A 2013 Multiple microvascular alterations in pancreatic islets and neuroendocrine tumors of a Men1 mouse model. American Journal of Pathology 182 2355-2367. (https://doi.org/10.1016/j.ajpath.2013.02.023)

Chunharojrith P, Nakayama Y, Jiang X, Kery RE, Ma J, De La Hoz Ulloa CS, Zhang X, Zhou Y \& Klibanski A 2015 Tumor suppression by MEG3 IncRNA in a human pituitary tumor derived cell line. Molecular and Cellular Endocrinology 416 27-35. (https://doi.org/10.1016/j. mce.2015.08.018)

Crabtree JS, Scacheri PC, Ward JM, Garrett-Beal L, Emmert-Buck MR, Edgemon KA, Lorang D, Libutti SK, Chandrasekharappa SC, Marx SJ, et al. 2001 A mouse model of multiple endocrine neoplasia, type 1, develops multiple endocrine tumors. PNAS 98 1118-1123. (https:// doi.org/10.1073/pnas.98.3.1118)

Crabtree JS, Scacheri PC, Ward JM, McNally SR, Swain GP, Montagna C, Hager JH, Hanahan D, Edlund H, Magnuson MA, et al. 2003 Of mice and MEN1: insulinomas in a conditional mouse knockout. Molecular and Cellular Biology 23 6075-6085. (https://doi.org/10.1128/ МСB.23.17.6075-6085.2003) 
Crona J \& Skogseid B 2016 GEP-NETS UPDATE: genetics of neuroendocrine tumors. European Journal of Endocrinology 174 R275-R290. (https://doi.org/10.1530/EJE-15-0972)

Cui M, Augert A, Rongione M, Conkrite K, Parazzoli S, Nikitin AY, Ingolia N \& MacPherson D 2014 PTEN is a potent suppressor of small cell lung cancer. Molecular Cancer Research 12 654-659. (https://doi. org/10.1158/1541-7786.MCR-13-0554)

Dai C, Zhang B, Liu X, Ma S, Yang Y, Yao Y, Feng M, Bao X, Li G, Wang J, et al. 2013 Inhibition of PI3K/AKT/mTOR pathway enhances temozolomide-induced cytotoxicity in pituitary adenoma cell lines in vitro and xenografted pituitary adenoma in female nude mice. Endocrinology 154 1247-1259. (https://doi.org/10.1210/en.2012-1908)

Daniel VC, Marchionni L, Hierman JS, Rhodes JT, Devereux WL, Rudin CM, Yung R, Parmigiani G, Dorsch M, Peacock CD, et al. 2009 A primary xenograft model of small-cell lung cancer reveals irreversible changes in gene expression imposed by culture in vitro. Cancer Research 69 3364-3373. (https://doi.org/10.1158/0008-5472. CAN-08-4210)

Dasari A, Shen C, Halperin D, Zhao B, Zhou S, Xu Y, Shih T \& Yao JC 2017 Trends in the incidence, prevalence, and survival outcomes in patients with neuroendocrine tumors in the United States. JAMA Oncology 3 1335-1342. (https://doi.org/10.1001/ jamaoncol.2017.0589)

Day C-P, Merlino G \& Van Dyke T 2015 Preclinical mouse cancer models a maze of opportunities and challenges. Cell 163 39-53. (https://doi. org/10.1016/j.cell.2015.08.068)

Diallo-Krou E, Yu J, Colby LA, Inoki K, Wilkinson JE, Thomas DG, Giordano TJ \& Koenig RJ 2009 Paired box gene 8-peroxisome proliferator-activated receptor-gamma fusion protein and loss of phosphatase and tensin homolog synergistically cause thyroid hyperplasia in transgenic mice. Endocrinology 150 5181-5190. (https://doi.org/10.1210/en.2009-0701)

Dincer HE, Podgaetz E \& Andrade RS 2015 Pulmonary neuroendocrine tumors: part I. Spectrum and characteristics of tumors. Journal of Bronchology and Interventional Pulmonology 22 267-273. (https://doi. org/10.1097/LBR.0000000000000157)

Dobson ME, Diallo-Krou E, Grachtchouk V, Yu J, Colby LA, Wilkinson JE, Giordano TJ \& Koenig RJ 2011 Pioglitazone induces a proadipogenic antitumor response in mice with PAX8-PPARgamma fusion protein thyroid carcinoma. Endocrinology 152 4455-4465. (https://doi. org/10.1210/en.2011-1178)

Doghman M, Karpova T, Rodrigues GA, Arhatte M, De Moura J, Cavalli LR, Virolle V, Barbry P, Zambetti GP, Figueiredo BC, et al. 2007 Increased steroidogenic factor-1 dosage triggers adrenocortical cell proliferation and cancer. Molecular Endocrinology 21 2968-2987. (https://doi.org/10.1210/me.2007-0120)

Donangelo I, Gutman S, Horvath E, Kovacs K, Wawrowsky K, Mount M \& Melmed S 2006 Pituitary tumor transforming gene overexpression facilitates pituitary tumor development. Endocrinology 147 4781-4791. (https://doi.org/10.1210/en.2006-0544)

Drapkin BJ, George J, Christensen CL, Mino-Kenudson M, Dries R, Sundaresan T, Phat S, Myers DT, Zhong J, Igo P, et al. 2018 Genomic and functional fidelity of small cell lung cancer patientderived xenografts. Cancer Discovery 8 600-615. (https://doi. org/10.1158/2159-8290.CD-17-0935)

Drelon C, Berthon A, Ragazzon B, Tissier F, Bandiera R, Sahut-Barnola I, de Joussineau C, Batisse-Lignier M, Lefrancois-Martinez A-M, Bertherat J, et al. 2012 Analysis of the role of Igf2 in adrenal tumour development in transgenic mouse models. PLOS ONE 7 e44171. (https://doi.org/10.1371/journal.pone.0044171)

Drucker DJ, Jin T, Asa SL, Young TA \& Brubaker PL 1994 Activation of proglucagon gene transcription by protein kinase-A in a novel mouse enteroendocrine cell line. Molecular Endocrinology 8 1646-1655. (https://doi.org/10.1210/mend.8.12.7535893)

Efrat S, Teitelman G, Anwar M, Ruggiero D \& Hanahan D 1988 Glucagon gene regulatory region directs oncoprotein expression to neurons and pancreatic alpha cells. Neuron 1 605-613. (https://doi. org/10.1016/0896-6273(88)90110-9)

Eirew P, Steif A, Khattra J, Ha G, Yap D, Farahani H, Gelmon K, Chia S, Mar C, Wan A, et al. 2015 Dynamics of genomic clones in breast cancer patient xenografts at single-cell resolution. Nature $\mathbf{5 1 8}$ 422-426. (https://doi.org/10.1038/nature13952)

Else T, Trovato A, Kim AC, Wu Y, Ferguson DO, Kuick RD, Lucas PC \& Hammer GD 2009 Genetic p53 deficiency partially rescues the adrenocortical dysplasia phenotype at the expense of increased tumorigenesis. Cancer Cell 15 465-476. (https://doi.org/10.1016/j. ccr.2009.04.011)

Ezzat S, Zheng L, Winer D \& Asa SL 2006 Targeting N-cadherin through fibroblast growth factor receptor-4: distinct pathogenetic and therapeutic implications. Molecular Endocrinology 20 2965-2975. (https://doi.org/10.1210/me.2006-0223)

Fassnacht M, Berruti A, Baudin E, Demeure MJ, Gilbert J, Haak H, Kroiss M, Quinn DI, Hesseltine E, Ronchi CL, et al. 2015 Linsitinib (OSI-906) versus placebo for patients with locally advanced or metastatic adrenocortical carcinoma: a double-blind, randomised, phase 3 study. Lancet Oncology 16 426-435. (https://doi.org/10.1016/ S1470-2045(15)70081-1)

Fedele M, Battista S, Kenyon L, Baldassarre G, Fidanza V, Klein-Szanto AJP, Parlow AF, Visone R, Pierantoni GM, Outwater E, et al. 2002 Overexpression of the HMGA2 gene in transgenic mice leads to the onset of pituitary adenomas. Oncogene 21 3190-3198. (https://doi. org/10.1038/sj.onc.1205428)

Fedele M, Pentimalli F, Baldassarre G, Battista S, Klein-Szanto AJP, Kenyon L, Visone R, De Martino I, Ciarmiello A, Arra C, et al. 2005 Transgenic mice overexpressing the wild-type form of the HMGA1 gene develop mixed growth hormone/prolactin cell pituitary adenomas and natural killer cell lymphomas. Oncogene 24 3427-3435. (https://doi.org/10.1038/sj.onc.1208501)

Fedele M, Visone R, De Martino I, Troncone G, Palmieri D, Battista S, Ciarmiello A, Pallante P, Arra C, Melillo RM, et al. 2006 HMGA2 induces pituitary tumorigenesis by enhancing E2F1 activity. Cancer Cell 9 459-471. (https://doi.org/10.1016/j.ccr.2006.04.024)

Fedele M, Palmieri D, Chiappetta G, Pasquinelli R, De Martino I, Arra C, Palma G, Valentino T, Pierantoni GM, Viglietto G, et al. 2009 Impairment of the p27kip1 function enhances thyroid carcinogenesis in TRK-T1 transgenic mice. Endocrine-Related Cancer 16 483-490. (https://doi.org/10.1677/ERC-08-0272)

Fero ML, Rivkin M, Tasch M, Porter P, Carow CE, Firpo E, Polyak K, Tsai LH, Broudy V, Perlmutter RM, et al. 1996 A syndrome of multiorgan hyperplasia with features of gigantism, tumorigenesis, and female sterility in p27(Kip1)-deficient mice. Cell 85 733-744. (https://doi.org/10.1016/S0092-8674(00)81239-8)

Fero ML, Randel E, Gurley KE, Roberts JM \& Kemp CJ 1998 The murine gene p27Kip1 is haplo-insufficient for tumour suppression. Nature 396 177-180. (https://doi.org/10.1038/24179)

Figueiredo BC, Cavalli LR, Pianovski MAD, Lalli E, Sandrini R, Ribeiro RC, Zambetti G, DeLacerda L, Rodrigues GA \& Haddad BR 2005 Amplification of the steroidogenic factor 1 gene in childhood adrenocortical tumors. Journal of Clinical Endocrinology and Metabolism 90 615-619. (https://doi.org/10.1210/jc. 2004-0942)

Fraedrich K, Schrader J, Ittrich H, Keller G, Gontarewicz A, Matzat V, Kromminga A, Pace A, Moll J, Blaker M, et al. 2012 Targeting aurora kinases with danusertib (PHA-739358) inhibits growth of liver metastases from gastroenteropancreatic neuroendocrine tumors in an orthotopic xenograft model. Clinical Cancer Research 18 4621-4632. (https://doi.org/10.1158/1078-0432.CCR-11-2968)

Franco AT, Malaguarnera R, Refetoff S, Liao X-H, Lundsmith E, Kimura S, Pritchard C, Marais R, Davies TF, Weinstein LS, et al. 2011 Thyrotrophin receptor signaling dependence of Braf-induced thyroid tumor initiation in mice. PNAS 108 1615-1620. (https://doi.org/10.1073/ pnas.1015557108) 
Franklin DS, Godfrey VL, Lee H, Kovalev GI, Schoonhoven R, ChenKiang S, Su L \& Xiong Y 1998 CDK inhibitors p18(INK4c) and p27(Kip1) mediate two separate pathways to collaboratively suppress pituitary tumorigenesis. Genes and Development 12 2899-2911. (https://doi.org/10.1101/gad.12.18.2899)

Frese KK \& Tuveson DA 2007 Maximizing mouse cancer models. Nature Reviews Cancer 7 645-658. (https://doi.org/10.1038/nrc2192)

Friis-Hansen L 2002 Gastric functions in gastrin gene knock-out mice. Pharmacology and Toxicology 91 363-367. (https://doi.org/10.1034/ j.1600-0773.2002.910614.x)

Friis-Hansen L, Sundler F, Li Y, Gillespie PJ, Saunders TL, Greenson JK, Owyang C, Rehfeld JF \& Samuelson LC 1998 Impaired gastric acid secretion in gastrin-deficient mice. American Journal of Physiology $\mathbf{2 7 4}$ G561-G568.

Fuertes M, Sapochnik M, Tedesco L, Senin S, Attorresi A, Ajler P, Carrizo G, Cervio A, Sevlever G, Bonfiglio JJ, et al. 2018 Protein stabilization by RSUME accounts for PTTG pituitary tumor abundance and oncogenicity. Endocrine-Related Cancer 25 665-676. (https://doi. org/10.1530/ERC-18-0028)

Furuya F, Lu C, Willingham MC \& Cheng S-Y 2007 Inhibition of phosphatidylinositol 3-kinase delays tumor progression and blocks metastatic spread in a mouse model of thyroid cancer. Carcinogenesis 28 2451-2458. (https://doi.org/10.1093/carcin/bgm174)

Gao H, Korn JM, Ferretti S, Monahan JE, Wang Y, Singh M, Zhang C, Schnell C, Yang G, Zhang Y, et al. 2015 High-throughput screening using patient-derived tumor xenografts to predict clinical trial drug response. Nature Medicine 21 1318-1325. (https://doi.org/10.1038/ nm.3954)

Gazdar AF, Savage TK, Johnson JE, Berns A, Sage J, Linnoila RI, MacPherson D, McFadden DG, Farago A, Jacks T, et al. 2015 The comparative pathology of genetically engineered mouse models for neuroendocrine carcinomas of the lung. Journal of Thoracic Oncology 10 553-564. (https://doi.org/10.1097/JTO.0000000000000459)

Gazdar AF, Bunn PA \& Minna JD 2017 Small-cell lung cancer: what we know, what we need to know and the path forward. Nature Reviews Cancer 17 725-737. (https://doi.org/10.1038/nrc.2017.87)

Gengenbacher N, Singhal M \& Augustin HG 2017 Preclinical mouse solid tumour models: status quo, challenges and perspectives. Nature Reviews Cancer 17 751-765. (https://doi.org/10.1038/nrc.2017.92)

George J, Lim JS, Jang SJ, Cun Y, Ozretic L, Kong G, Leenders F, Lu X, Fernandez-Cuesta L, Bosco G, et al. 2015 Comprehensive genomic profiles of small cell lung cancer. Nature 524 47-53. (https://doi. org/10.1038/nature14664)

Gillet J-P, Calcagno AM, Varma S, Marino M, Green LJ, Vora MI, Patel C, Orina JN, Eliseeva TA, Singal V, et al. 2011 Redefining the relevance of established cancer cell lines to the study of mechanisms of clinical anti-cancer drug resistance. PNAS 108 18708-18713. (https://doi. org/10.1073/pnas.1111840108)

Giordano TJ 201865 YEARS OF THE DOUBLE HELIX: Classification of endocrine tumors in the age of integrated genomics. Endocrine-Related Cancer 25 T171-T187. (https://doi.org/10.1530/ERC-18-0116)

Goswamy J, Lei M \& Simo R 2016 Parathyroid carcinoma. Current Opinion in Otolaryngology and Head and Neck Surgery 24 155-162. (https://doi. org/10.1097/MOO.0000000000000234)

Grant SG, Seidman I, Hanahan D \& Bautch VL 1991 Early invasiveness characterizes metastatic carcinoid tumors in transgenic mice. Cancer Research 51 4917-4923.

Gross DJ, Reibstein I, Weiss L, Slavin S, Stein I, Neeman M, Abramovitch R \& Benjamin LE 1999 The antiangiogenic agent linomide inhibits the growth rate of von Hippel-Lindau paraganglioma xenografts to mice. Clinical Cancer Research 5 3669-3675.

Guidi CJ, Mudhasani R, Hoover K, Koff A, Leav I, Imbalzano AN \& Jones SN 2006 Functional interaction of the retinoblastoma and Ini1/Snf5 tumor suppressors in cell growth and pituitary tumorigenesis. Cancer Research 66 8076-8082. (https://doi.org/10.1158/0008-5472.CAN-06-1451)
Gum JR Jr, Hicks JW, Crawley SC, Yang SC, Borowsky AD, Dahl CM, Kakar S, Kim DH, Cardiff RD \& Kim YS 2004 Mice expressing SV40 $\mathrm{T}$ antigen directed by the intestinal trefoil factor promoter develop tumors resembling human small cell carcinoma of the colon. Molecular Cancer Research 2 504-513.

Gyory F, Mezosi E, Szakall S, Bajnok L, Varga E, Borbely A, Gazdag A, Juhasz I, Lukacs G \& Nagy EV 2005 Establishment of the hu-PBL-SCID mouse model for the investigation of thyroid cancer. Experimental and Clinical Endocrinology and Diabetes 113 359-364. (https://doi. org/10.1055/s-2005-865740)

Hadoux J, Feraud O, Griscelli F, Opolon P, Divers D, Gobbo E, Schlumberger M, Bennaceur-Griscelli A \& Turhan AG 2016 Generation of an induced pluripotent stem cell line from a patient with hereditary multiple endocrine neoplasia 2A (MEN2A) syndrome with RET mutation. Stem Cell Research 17 154-157. (https://doi. org/10.1016/j.scr.2016.06.008)

Hanahan D 1985 Heritable formation of pancreatic beta-cell tumours in transgenic mice expressing recombinant insulin/simian virus 40 oncogenes. Nature 315 115-122. (https://doi.org/10.1038/315115a0)

Hantel C, Lewrick F, Reincke M, Suss R \& Beuschlein F 2012 Liposomal doxorubicin-based treatment in a preclinical model of adrenocortical carcinoma. Journal of Endocrinology 213 155-161. (https://doi. org/10.1530/JOE-11-0427)

Hantel C, Jung S, Mussack T, Reincke M \& Beuschlein F 2014 Liposomal polychemotherapy improves adrenocortical carcinoma treatment in a preclinical rodent model. Endocrine-Related Cancer 21 383-394. (https://doi.org/10.1530/ERC-13-0439)

Harada N, Tamai Y, Ishikawa T, Sauer B, Takaku K, Oshima M \& Taketo MM 1999 Intestinal polyposis in mice with a dominant stable mutation of the beta-catenin gene. EMBO Journal 18 5931-5942. (https://doi.org/10.1093/emboj/18.21.5931)

Harvey M, Vogel H, Lee EY, Bradley A \& Donehower LA 1995 Mice deficient in both p53 and $\mathrm{Rb}$ develop tumors primarily of endocrine origin. Cancer Research 55 1146-1151.

Heaton JH, Wood MA, Kim AC, Lima LO, Barlaskar FM, Almeida MQ, Fraegoso MCBV, Kuick R, Lerario AM, Simon DP, et al. 2012 Progression to adrenocortical tumorigenesis in mice and humans through insulin-like growth factor 2 and beta-catenin. American Journal of Pathology 181 1017-1033. (https://doi.org/10.1016/j. ajpath.2012.05.026)

Helseth A, Siegal GP, Haug E \& Bautch VL 1992 Transgenic mice that develop pituitary tumors. A model for Cushing's disease. American Journal of Pathology 140 1071-1080.

Hidalgo M, Amant F, Biankin AV, Budinska E, Byrne AT, Caldas C, Clarke RB, de Jong S, Jonkers J, Malandsmo GM, et al. 2014 Patientderived xenograft models: an emerging platform for translational cancer research. Cancer Discovery 4 998-1013. (https://doi. org/10.1158/2159-8290.CD-14-0001)

Ho AL, Grewal RK, Leboeuf R, Sherman EJ, Pfister DG, Deandreis D, Pentlow KS, Zanzonico PB, Haque S, Gavane S, et al. 2013 Selumetinib-enhanced radioiodine uptake in advanced thyroid cancer. New England Journal of Medicine 368 623-632. (https://doi. org/10.1056/NEJMoa1209288)

Jacks T, Fazeli A, Schmitt EM, Bronson RT, Goodell MA \& Weinberg RA 1992 Effects of an Rb mutation in the mouse. Nature 359 295-300. (https://doi.org/10.1038/359295a0)

Jahchan NS, Lim JS, Bola B, Morris K, Seitz G, Tran KQ, Xu L, Trapani F, Morrow CJ, Cristea S, et al. 2016 Identification and targeting of longterm tumor-propagating cells in small cell lung cancer. Cell Reports $\mathbf{1 6}$ 644-656. (https://doi.org/10.1016/j.celrep.2016.06.021)

Jalali S, Monsalves E, Tateno T \& Zadeh G 2016 Role of mTOR inhibitors in growth hormone-producing pituitary adenomas harboring different FGFR4 genotypes. Endocrinology 157 3577-3587. (https:// doi.org/10.1210/en.2016-1028)

Jiang J, Wang DD, Yang M, Chen D, Pang L, Guo S, Cai J, Wery JP, Li L, Li HQ, et al. 2015 Comprehensive characterization of 
chemotherapeutic efficacy on metastases in the established gastric neuroendocrine cancer patient derived xenograft model. Oncotarget 6 15639-15651. (https://doi.org/10.18632/oncotarget.3712)

Jimenez C \& Gagel RF 2004 Genetic testing in endocrinology: lessons learned from experience with multiple endocrine neoplasia type 2 (MEN2). Growth Hormone and IGF Research 14 (Supplement A) S150-S157. (https://doi.org/10.1016/j.ghir.2004.03.033)

Johnbeck CB, Munk Jensen M, Haagen Nielsen C, Fisker Hag AM, Knigge U \& Kjaer A 2014 18F-FDG and 18F-FLT-PET imaging for monitoring everolimus effect on tumor-growth in neuroendocrine tumors: studies in human tumor xenografts in mice. PLoS ONE 9 e91387. (https://doi.org/10.1371/journal.pone.0091387)

Kalkan E \& Waguespack SG 2013 Endocrine tumors associated with neurofibromatosis type 1, Peutz-Jeghers syndrome and other familial neoplasia syndromes. Frontiers of Hormone Research 41 166-181. (https://doi.org/10.1159/000345676)

Kato Y, Ying H, Willingham MC \& Cheng S-Y 2004 A tumor suppressor role for thyroid hormone beta receptor in a mouse model of thyroid carcinogenesis. Endocrinology 145 4430-4438. (https://doi. org/10.1210/en.2004-0612)

Kemp CJ 2015 Animal models of chemical carcinogenesis: driving breakthroughs in cancer research for 100 years. Cold Spring Harbor Protocols 2015 865-874. (https://doi.org/10.1101/pdb.top069906)

Kersten K, de Visser KE, van Miltenburg MH \& Jonkers J 2017 Genetically engineered mouse models in oncology research and cancer medicine. EMBO Molecular Medicine 9 137-153. (https://doi.org/10.15252/ emmm.201606857)

Kim WG, Zhao L, Kim DW, Willingham MC \& Cheng S-y 2014 Inhibition of tumorigenesis by the thyroid hormone receptor beta in xenograft models. Thyroid 24 260-269. (https://doi.org/10.1089/ thy.2013.0054)

Kiyokawa H, Kineman RD, Manova-Todorova KO, Soares VC, Hoffman ES, Ono M, Khanam D, Hayday AC, Frohman LA \& Koff A 1996 Enhanced growth of mice lacking the cyclin-dependent kinase inhibitor function of p27(Kip1). Cell 85 721-732. (https://doi. org/10.1016/S0092-8674(00)81238-6)

Kloos A, Woller N, Gurlevik E, Ureche CI, Niemann J, Armbrecht N, Martin NT, Geffers R, Manns MP, Gerardy-Schahn R, et al. 2015 PolySia-specific retargeting of oncolytic viruses triggers tumorspecific immune responses and facilitates therapy of disseminated lung cancer. Cancer Immunology Research 3 751-763. (https://doi. org/10.1158/2326-6066.CIR-14-0124-T)

Kolby L, Bernhardt P, Ahlman H, Wangberg B, Johanson V, Wigander A, Forssell-Aronsson E, Karlsson S, Ahren B, Stenman G, et al. 2001 A transplantable human carcinoid as model for somatostatin receptormediated and amine transporter-mediated radionuclide uptake. American Journal of Pathology 158 745-755. (https://doi.org/10.1016/ S0002-9440(10)64017-5)

Krieg A, Mersch S, Boeck I, Dizdar L, Weihe E, Hilal Z, Krausch M, Mohlendick B, Topp SA, Piekorz RP, et al. 2014 New model for gastroenteropancreatic large-cell neuroendocrine carcinoma: establishment of two clinically relevant cell lines. PLoS ONE 9 e88713. (https://doi.org/10.1371/journal.pone.0088713)

Kumar TR, Graham KE, Asa SL \& Low MJ 1998 Simian virus 40 T antigen-induced gonadotroph adenomas: a model of human null cell adenomas. Endocrinology 139 3342-3351. (https://doi.org/10.1210/ endo.139.7.6100)

La Perle KM, Jhiang SM \& Capen CC 2000 Loss of p53 promotes anaplasia and local invasion in ret/PTC1-induced thyroid carcinomas. American Journal of Pathology 157 671-677. (https://doi.org/10.1016/ S0002-9440(10)64577-4)

Lambert-Langlais S, Val P, Guyot S, Ragazzon B, Sahut-Barnola I, De Haze A, Lefrancois-Martinez A-M \& Martinez A 2009 A transgenic mouse line with specific Cre recombinase expression in the adrenal cortex. Molecular and Cellular Endocrinology 300 197-204. (https://doi. org/10.1016/j.mce.2008.10.045)
Landis MD, Lehmann BD, Pietenpol JA \& Chang JC 2013 Patient-derived breast tumor xenografts facilitating personalized cancer therapy. Breast Cancer Research 15 201. (https://doi.org/10.1186/bcr3355)

Leach DR, Krummel MF \& Allison JP 1996 Enhancement of antitumor immunity by CTLA-4 blockade. Science 271 1734-1736. (https://doi. org/10.1126/science.271.5256.1734)

Ledent C, Dumont J, Vassart G \& Parmentier M 1991 Thyroid adenocarcinomas secondary to tissue-specific expression of simian virus-40 large T-antigen in transgenic mice. Endocrinology 129 1391-1401. (https://doi.org/10.1210/endo-129-3-1391)

Lee M \& Pellegata NS 2013 Multiple endocrine neoplasia type 4. Frontiers of Hormone Research 41 63-78. (https://doi.org/10.1159/000345670)

Lee YC, Asa SL \& Drucker DJ 1992 Glucagon gene 5'-flanking sequences direct expression of simian virus 40 large $\mathrm{T}$ antigen to the intestine, producing carcinoma of the large bowel in transgenic mice. Journal of Biological Chemistry 267 10705-10708.

Lee HJ, Lee WK, Kang CW, Ku CR, Cho YH \& Lee EJ 2018 A selective cyclin-dependent kinase 4, 6 dual inhibitor, Ribociclib (LEE011) inhibits cell proliferation and induces apoptosis in aggressive thyroid cancer. Cancer Letters 417 131-140. (https://doi.org/10.1016/j. canlet.2017.12.037)

Leontiou CA, Gueorguiev M, van der Spuy J, Quinton R, Lolli F, Hassan S, Chahal HS, Igreja SC, Jordan S, Rowe J, et al. 2008 The role of the aryl hydrocarbon receptor-interacting protein gene in familial and sporadic pituitary adenomas. Journal of Clinical Endocrinology and Metabolism 93 2390-2401. (https://doi.org/10.1210/jc.2007-2611)

Lepoutre-Lussey C, Thibault C, Buffet A, Morin A, Badoual C, Benit P, Rustin P, Ottolenghi C, Janin M, Castro-Vega L-J, et al. 2016 From Nf1 to Sdhb knockout: successes and failures in the quest for animal models of pheochromocytoma. Molecular and Cellular Endocrinology 421 40-48. (https://doi.org/10.1016/j.mce.2015.06.027)

Li Q, Su Z, Liu J, Cai L, Lu J, Lin S, Xiong Z, Li W, Zheng W, Wu J, et al. 2014 Dopamine receptor D2S gene transfer improves the sensitivity of GH3 rat pituitary adenoma cells to bromocriptine. Molecular and Cellular Endocrinology 382 377-384. (https://doi.org/10.1016/j. mce.2013.10.021)

Li R, Zhang Z, Wang J, Huang Y, Sun W, Xie R, Hu F \& Lei T 2017 Triptolide suppresses growth and hormone secretion in murine pituitary corticotroph tumor cells via NF-kappaB signaling pathway. Biomedicine and Pharmacotherapy 95 771-779. (https://doi. org/10.1016/j.biopha.2017.08.127)

Libutti SK, Crabtree JS, Lorang D, Burns AL, Mazzanti C, Hewitt SM, O'Connor S, Ward JM, Emmert-Buck MR, Remaley A, et al. 2003 Parathyroid gland-specific deletion of the mouse Men1 gene results in parathyroid neoplasia and hypercalcemic hyperparathyroidism. Cancer Research 63 8022-8028.

Lin SJ, Leng ZG, Guo YH, Cai L, Cai Y, Li N, Shang HB, Le WD, Zhao WG $\&$ Wu ZB 2015 Suppression of mTOR pathway and induction of autophagy-dependent cell death by cabergoline. Oncotarget 6 39329-39341. (https://doi.org/10.18632/oncotarget.5744)

Lin SJ, Wu ZR, Cao L, Zhang Y, Leng ZG, Guo YH, Shang HB, Zhao WG, Zhang X \& Wu ZB 2017 Pituitary tumor suppression by combination of cabergoline and chloroquine. Journal of Clinical Endocrinology and Metabolism 102 3692-3703. (https://doi. org/10.1210/jc.2017-00627)

Lin S-F, Lin J-D, Hsueh C, Chou T-C \& Wong RJ 2018 Activity of roniciclib in medullary thyroid cancer. Oncotarget 9 28030-28041. (https://doi.org/10.18632/oncotarget.25555)

Lines KE, Stevenson M \& Thakker RV 2016 Animal models of pituitary neoplasia. Molecular and Cellular Endocrinology 421 68-81. (https:// doi.org/10.1016/j.mce.2015.08.024)

Linnoila RI, Sahu A, Miki M, Ball DW \& DeMayo FJ 2000 Morphometric analysis of CC10-hASH1 transgenic mouse lung: a model for bronchiolization of alveoli and neuroendocrine carcinoma. Experimental Lung Research 26 595-615. (https://doi. org/10.1080/01902140150216693) 
Liu F, Yu X, Huang H, Chen X, Wang J, Zhang X \& Lin Q 2016 Upregulation of microRNA-450 inhibits the progression of lung cancer in vitro and in vivo by targeting interferon regulatory factor 2. International Journal of Molecular Medicine 38 283-290. (https://doi. org/10.3892/ijmm.2016.2612)

Lloyd RV, Ruebel KH, Zhang S \& Jin L 2002 Pituitary hyperplasia in glycoprotein hormone alpha subunit-, p18(INK4C)-, and p27(kip1)-null mice: analysis of proteins influencing p27(kip-1) ubiquitin degradation. American Journal of Pathology 160 1171-1179. (https:// doi.org/10.1016/S0002-9440(10)64936-X)

Loffler KA, Biondi CA, Gartside M, Waring P, Stark M, Serewko-Auret MM, Muller HK, Hayward NK \& Kay GF 2007a Broad tumor spectrum in a mouse model of multiple endocrine neoplasia type 1. International Journal of Cancer 120 259-267. (https://doi.org/10.1002/ijc.22288)

Loffler KA, Biondi CA, Gartside MG, Serewko-Auret MM, Duncan R, Tonks ID, Mould AW, Waring P, Muller HK, Kay GF, et al. 2007b Lack of augmentation of tumor spectrum or severity in dual heterozygous Men1 and Rb1 knockout mice. Oncogene 26 4009-4017. (https://doi. org/10.1038/sj.onc.1210163)

Logie A, Boudou P, Boccon-Gibod L, Baudin E, Vassal G, Schlumberger M, Le Bouc Y \& Gicquel C 2000 Establishment and characterization of a human adrenocortical carcinoma xenograft model. Endocrinology 141 3165-3171. (https://doi.org/10.1210/endo.141.9.7668)

Lok BH, Gardner EE, Schneeberger VE, Ni A, Desmeules P, Rekhtman N, de Stanchina E, Teicher BA, Riaz N, Powell SN, et al. 2017 PARP inhibitor activity correlates with SLFN11 expression and demonstrates synergy with temozolomide in small cell lung cancer. Clinical Cancer Research 23 523-535. (https://doi.org/10.1158/1078-0432.CCR-161040)

Lombardo GE, Maggisano V, Celano M, Cosco D, Mignogna C, Baldan F, Lepore SM, Allegri L, Moretti S, Durante C, et al. 2018 Anti-hTERT siRNA-loaded nanoparticles block the growth of anaplastic thyroid cancer xenograft. Molecular Cancer Therapeutics 17 1187-1195. (https://doi.org/10.1158/1535-7163.MCT-17-0559)

Lou I, Odorico S, Yu X-M, Harrison A, Jaskula-Sztul R \& Chen H 2018 Notch3 as a novel therapeutic target in metastatic medullary thyroid cancer. Surgery 163 104-111. (https://doi.org/10.1016/j. surg.2017.07.039)

Low MJ, Liu B, Hammer GD, Rubinstein M \& Allen RG 1993 Posttranslational processing of proopiomelanocortin (POMC) in mouse pituitary melanotroph tumors induced by a POMC-simian virus 40 large T antigen transgene. Journal of Biological Chemistry 268 24967-24975.

Lu J, Chatain GP, Bugarini A, Wang X, Maric D, Walbridge S, Zhuang Z \& Chittiboina P 2017 Histone deacetylase inhibitor SAHA is a promising treatment of Cushing disease. Journal of Clinical Endocrinology and Metabolism 102 2825-2835. (https://doi.org/10.1210/jc.2017-00464)

Luque RM, Soares BS, Peng XD, Krishnan S, Cordoba-Chacon J, Frohman LA \& Kineman RD 2009 Use of the metallothionein promoter-human growth hormone-releasing hormone (GHRH) mouse to identify regulatory pathways that suppress pituitary somatotrope hyperplasia and adenoma formation due to GHRHreceptor hyperactivation. Endocrinology 150 3177-3185. (https://doi. org/10.1210/en.2008-1482)

Ma S, Jia W \& Ni S 2018 miR-199a-5p inhibits the progression of papillary thyroid carcinoma by targeting SNAI1. Biochemical and Biophysical Research Communications 497 181-186. (https://doi.org/10.1016/j. bbrc.2018.02.051)

Mannelli M, Cantini G, Poli G, Mangoni M, Nesi G, Canu L, Rapizzi E, Borgogni E, Ercolino T, Piccini V, et al. 2010 Role of the PPAR-gamma system in normal and tumoral pituitary corticotropic cells and adrenal cells. Neuroendocrinology 92 (Supplement 1) 23-27. (https:// doi.org/10.1159/000314312)

Manoharan J, Fendrich V, Di Fazio P, Bollmann C, Roth S, Joos B, Mintziras I, Albers M, Ramaswamy A, Bertolino P, et al. 2018 Chemoprevention with enalapril and aspirin in Men1(+/T) knockout mouse model. Neuroendocrinology 107 257-266. (https://doi. org/10.1159/000492224)

Manoranjan B, Mahendram S, Almenawer SA, Venugopal C, McFarlane N, Hallett R, Vijayakumar T, Algird A, Murty NK, Sommer DD, et al. 2016 The identification of human pituitary adenoma-initiating cells. Acta Neuropathologica Communications 4 125. (https://doi.org/10.1186/ s40478-016-0394-4)

Mariniello B, Rosato A, Zuccolotto G, Rubin B, Cicala MV, Finco I, Iacobone M, Frigo AC, Fassina A, Pezzani R, et al. 2012 Combination of sorafenib and everolimus impacts therapeutically on adrenocortical tumor models. Endocrine-Related Cancer 19 527-539. (https://doi. org/10.1530/ERC-11-0337)

McFadden DG, Papagiannakopoulos T, Taylor-Weiner A, Stewart C, Carter SL, Cibulskis K, Bhutkar A, McKenna A, Dooley A, Vernon A, et al. 2014a Genetic and clonal dissection of murine small cell lung carcinoma progression by genome sequencing. Cell 156 1298-1311. (https://doi.org/10.1016/j.cell.2014.02.031)

McFadden DG, Vernon A, Santiago PM, Martinez-McFaline R, Bhutkar A, Crowley DM, McMahon M, Sadow PM \& Jacks T $2014 b$ p53 constrains progression to anaplastic thyroid carcinoma in a Braf-mutant mouse model of papillary thyroid cancer. PNAS $\mathbf{1 1 1}$ E1600-E1609. (https://doi.org/10.1073/pnas.1404357111)

McSheehy PM, Troy H, Kelland LR, Judson IR, Leach MO \& Griffiths JR 2003 Increased tumour extracellular $\mathrm{pH}$ induced by Bafilomycin A1 inhibits tumour growth and mitosis in vivo and alters 5 -fluorouracil pharmacokinetics. European Journal of Cancer 39 532-540. (https://doi. org/10.1016/S0959-8049(02)00671-8)

Mellon SH, Miller WL, Bair SR, Moore CC, Vigne JL \& Weiner RI 1994 Steroidogenic adrenocortical cell lines produced by genetically targeted tumorigenesis in transgenic mice. Molecular Endocrinology $\mathbf{8}$ 97-108. (https://doi.org/10.1210/mend.8.1.8152434)

Melmed S 2011 Pathogenesis of pituitary tumors. Nature Reviews Endocrinology 7 257-266. (https://doi.org/10.1038/nrendo.2011.40)

Merlo A, Bernardo-Castineira C, Saenz-de-Santa-Maria I, Pitiot AS, Balbin M, Astudillo A, Valdes N, Scola B, Del Toro R, Mendez-Ferrer S, et al. 2017 Role of VHL, HIF1A and SDH on the expression of miR210: implications for tumoral pseudo-hypoxic fate. Oncotarget 8 6700-6717. (https://doi.org/10.18632/oncotarget.14265)

Meuwissen R, Linn SC, Linnoila RI, Zevenhoven J, Mooi WJ \& Berns A 2003 Induction of small cell lung cancer by somatic inactivation of both Trp53 and Rb1 in a conditional mouse model. Cancer Cell 4 181-189. (https://doi.org/10.1016/S1535-6108(03)00220-4)

Michiels FM, Chappuis S, Caillou B, Pasini A, Talbot M, Monier R, Lenoir GM, Feunteun J \& Billaud M 1997 Development of medullary thyroid carcinoma in transgenic mice expressing the RET protooncogene altered by a multiple endocrine neoplasia type 2A mutation. PNAS 94 3330-3335. (https://doi.org/10.1073/pnas.94.7.3330)

Mohr H \& Pellegata NS 2017 Animal models of MEN1. Endocrine-Related Cancer 24 T161-T177. (https://doi.org/10.1530/ERC-17-0249)

Mokhtari RB, Kumar S, Islam SS, Yazdanpanah M, Adeli K, Cutz E \& Yeger H 2013 Combination of carbonic anhydrase inhibitor, acetazolamide, and sulforaphane, reduces the viability and growth of bronchial carcinoid cell lines. BMC Cancer 13 378. (https://doi. org/10.1186/1471-2407-13-378)

Nakayama K, Ishida N, Shirane M, Inomata A, Inoue T, Shishido N, Horii I, Loh DY \& Nakayama K 1996 Mice lacking p27(Kip1) display increased body size, multiple organ hyperplasia, retinal dysplasia, and pituitary tumors. Cell 85 707-720. (https://doi.org/10.1016/S00928674(00)81237-4)

Nassar D, Latil M, Boeckx B, Lambrechts D \& Blanpain C 2015 Genomic landscape of carcinogen-induced and genetically induced mouse skin squamous cell carcinoma. Nature Medicine 21 946-954. (https://doi. org $/ 10.1038 / \mathrm{nm} .3878)$

Nikiforova MN \& Nikiforov YE 2009 Molecular diagnostics and predictors in thyroid cancer. Thyroid 19 1351-1361. (https://doi.org/10.1089/ thy.2009.0240) 
Nilsson O, Kolby L, Bernhardt P, Forssell-Aronsson E, Johanson V \& Ahlman H 2004 GOT1 xenografted to nude mice: a unique model for in vivo studies on SSTR-mediated radiation therapy of carcinoid tumors. Annals of the New York Academy of Sciences 1014 275-279. (https://doi.org/10.1196/annals.1294.031)

Ning S, Knox SJ, Harsh GR, Culler MD \& Katznelson L 2009 Lanreotide promotes apoptosis and is not radioprotective in GH3 cells. EndocrineRelated Cancer 16 1045-1055. (https://doi.org/10.1677/ERC-09-0003)

Oberg K 2013 The genetics of neuroendocrine tumors. Seminars in Oncology 40 37-44. (https://doi.org/10.1053/j. seminoncol.2012.11.005)

Oberg K 2018 The genesis of the neuroendocrine tumors concept: from oberndorfer to 2018. Endocrinology and Metabolism Clinics of North America 47 711-731. (https://doi.org/10.1016/j.ecl.2018.05.003)

Oberg K, Casanovas O, Castano JP, Chung D, Delle Fave G, Denefle P, Harris P, Khan MS, Kulke MH, Scarpa A, et al. 2013 Molecular pathogenesis of neuroendocrine tumors: implications for current and future therapeutic approaches. Clinical Cancer Research 19 2842-2849. (https://doi.org/10.1158/1078-0432.CCR-12-3458)

Odate S, Onishi H, Nakamura K, Kojima M, Uchiyama A, Kato M \& Katano M 2013 Tropomyosin-related kinase B inhibitor has potential for tumor regression and relapse prevention in pulmonary large cell neuroendocrine carcinoma. Anticancer Research 33 3699-3703.

Onrust SV, Hartl PM, Rosen SD \& Hanahan D 1996 Modulation of L-selectin ligand expression during an immune response accompanying tumorigenesis in transgenic mice. Journal of Clinical Investigation 97 54-64. (https://doi.org/10.1172/JCI118406)

Owonikoko TK, Zhang G, Kim HS, Stinson RM, Bechara R, Zhang C, Chen Z, Saba NF, Pakkala S, Pillai R, et al. 2016 Patient-derived xenografts faithfully replicated clinical outcome in a phase II co-clinical trial of arsenic trioxide in relapsed small cell lung cancer. Journal of Translational Medicine 14 111. (https://doi.org/10.1186/ s12967-016-0861-5)

Oxboel J, Brandt-Larsen M, Schjoeth-Eskesen C, Myschetzky R, El-Ali HH Madsen J \& Kjaer A 2014 Comparison of two new angiogenesis PET tracers 68Ga-NODAGA-E[c(RGDyK)]2 and (64)Cu-NODAGA$\mathrm{E}[\mathrm{C}(\mathrm{RGDyK})] 2$; in vivo imaging studies in human xenograft tumors. Nuclear Medicine and Biology 41 259-267. (https://doi.org/10.1016/j. nucmedbio.2013.12.003)

Pacheco MC 2016 Multiple endocrine neoplasia: a genetically diverse group of familial tumor syndromes. Journal of Pediatric Genetics $\mathbf{5}$ 89-97. (https://doi.org/10.1055/s-0036-1579758)

Pedraza-Arevalo S, Gahete MD, Alors-Perez E, Luque RM \& Castano JP 2018 Multilayered heterogeneity as an intrinsic hallmark of neuroendocrine tumors. Reviews in Endocrine and Metabolic Disorders 19 179-192. (https://doi.org/10.1007/s11154-018-9465-0)

Pei L \& Melmed S 1997 Isolation and characterization of a pituitary tumor-transforming gene (PTTG). Molecular Endocrinology 11 433-441. (https://doi.org/10.1210/mend.11.4.9911)

Pelosi G, Sonzogni A, Harari S, Albini A, Bresaola E, Marchio C, Massa F, Righi L, Gatti G, Papanikolaou N, et al. 2017 Classification of pulmonary neuroendocrine tumors: new insights. Translational Lung Cancer Research 6 513-529. (https://doi.org/10.21037/tlcr.2017.09.04)

Pestourie C, Theze B, Kuhnast B, Le Helleix S, Gombert K, Dolle F, Tavitian B \& Duconge F 2010 PET imaging of medullary thyroid carcinoma in MEN2A transgenic mice using 6-[(18)F]F-L-DOPA. European Journal of Nuclear Medicine and Molecular Imaging 37 58-66. (https://doi.org/10.1007/s00259-009-1208-8)

Petersen AL, Binderup T, Jolck RI, Rasmussen P, Henriksen JR, Pfeifer AK, Kjaer A \& Andresen TL 2012 Positron emission tomography evaluation of somatostatin receptor targeted 64Cu-TATE-liposomes in a human neuroendocrine carcinoma mouse model. Journal of Controlled Release 160 254-263. (https://doi.org/10.1016/j. jconrel.2011.12.038)

Pettengill OS, Memoli VA, Brinck-Johnsen T \& Longnecker DS 1994 Cell lines derived from pancreatic tumors of Tg(Ela-1-SV40E)Bri18 transgenic mice express somatostatin and T antigen. Carcinogenesis $\mathbf{1 5}$ 61-65. (https://doi.org/10.1093/carcin/15.1.61)

Pfragner R, Wirnsberger G, Niederle B, Behmel A, Rinner I, Mandl A, Wawrina F, Luo J, Adamiker D, Hoger H, et al. 1996 Establishment of a continuous cell line from a human carcinoid of the small intestine (KRJ-I). International Journal of Oncology 8 513-520.

Pietras K \& Hanahan D 2005 A multitargeted, metronomic, and maximum-tolerated dose 'chemo-switch' regimen is antiangiogenic, producing objective responses and survival benefit in a mouse model of cancer. Journal of Clinical Oncology 23 939-952. (https://doi. org/10.1200/JCO.2005.07.093)

Pinto EM, Morton C, Rodriguez-Galindo C, McGregor L, Davidoff AM, Mercer K, Debelenko LV, Billups C, Ribeiro RC \& Zambetti GP 2013 Establishment and characterization of the first pediatric adrenocortical carcinoma xenograft model identifies topotecan as a potential chemotherapeutic agent. Clinical Cancer Research 19 1740-1747. (https://doi.org/10.1158/1078-0432.CCR-12-3354)

Piret SE \& Thakker RV 2011 Mouse models for inherited endocrine and metabolic disorders. Journal of Endocrinology 211 211-230. (https:// doi.org/10.1530/JOE-11-0193)

Powell DJ Jr, Russell J, Nibu K, Li G, Rhee E, Liao M, Goldstein M, Keane WM, Santoro M, Fusco A, et al. 1998 The RET/PTC3 oncogene: metastatic solid-type papillary carcinomas in murine thyroids. Cancer Research 58 5523-5528.

Powell DJ Jr, Russell JP, Li G, Kuo BA, Fidanza V, Huebner K \& Rothstein JL 2001 Altered gene expression in immunogenic poorly differentiated thyroid carcinomas from RET/PTC3p53-/- mice. Oncogene 20 3235-3246. (https://doi.org/10.1038/sj.onc.1204425)

Powers JF, Evinger MJ, Zhi J, Picard KL \& Tischler AS 2007 Pheochromocytomas in Nf1 knockout mice express a neural progenitor gene expression profile. Neuroscience 147 928-937. (https://doi.org/10.1016/j.neuroscience.2007.05.008)

Pozo K, Castro-Rivera E, Tan C, Plattner F, Schwach G, Siegl V, Meyer D, Guo A, Gundara J, Mettlach G, et al. 2013 The role of Cdk5 in neuroendocrine thyroid cancer. Cancer Cell 24 499-511. (https://doi. org/10.1016/j.ccr.2013.08.027)

Pringle DR, Vasko VV, Yu L, Manchanda PK, Lee AA, Zhang X, Kirschner JM, Parlow AF, Saji M, Jarjoura D, et al. 2014 Follicular thyroid cancers demonstrate dual activation of PKA and mTOR as modeled by thyroid-specific deletion of Prkar1a and Pten in mice. Journal of Clinical Endocrinology and Metabolism 99 E804-E812. (https://doi.org/10.1210/jc.2013-3101)

Pringle DR, Yin Z, Lee AA, Manchanda PK, Yu L, Parlow AF, Jarjoura D, La Perle KMD \& Kirschner LS 2012 Thyroid-specific ablation of the Carney complex gene, PRKAR1A, results in hyperthyroidism and follicular thyroid cancer. Endocrine-Related Cancer 19 435-446. (https://doi.org/10.1530/ERC-11-0306)

Quinn TJ, Yuan Z, Adem A, Geha R, Vrikshajanani C, Koba W, Fine E, Hughes DT, Schmid HA \& Libutti SK 2012 Pasireotide (SOM230) is effective for the treatment of pancreatic neuroendocrine tumors (PNETs) in a multiple endocrine neoplasia type 1 (MEN1) conditional knockout mouse model. Surgery 152 1068-1077. (https://doi. org/10.1016/j.surg.2012.08.021)

Raitila A, Lehtonen HJ, Arola J, Heliovaara E, Ahlsten M, Georgitsi M, Jalanko A, Paetau A, Aaltonen LA \& Karhu A 2010 Mice with inactivation of aryl hydrocarbon receptor-interacting protein (Aip) display complete penetrance of pituitary adenomas with aberrant ARNT expression. American Journal of Pathology 177 1969-1976. (https://doi.org/10.2353/ajpath.2010.100138)

Randle RW, Northrup SA, Sirintrapun SJ, Lyles DS \& Stewart JHt 2013 Oncolytic vesicular stomatitis virus as a treatment for neuroendocrine tumors. Surgery 154 1323-1329; discussion 1329-1330. (https://doi. org/10.1016/j.surg.2013.04.050)

Raymond E, Dahan L, Raoul J-L, Bang Y-J, Borbath I, Lombard-Bohas C, Valle J, Metrakos P, Smith D, Vinik A, et al. 2011 Sunitinib malate for the treatment of pancreatic neuroendocrine tumors. 
New England Journal of Medicine 364 501-513. (https://doi. org/10.1056/NEJMoa1003825)

Ribeiro-Neto F, Leon A, Urbani-Brocard J, Lou L, Nyska A \& Altschuler DI 2004 cAMP-dependent oncogenic action of Rap1b in the thyroid gland. Journal of Biological Chemistry 279 46868-46875. (https://doi. org/10.1074/jbc.M406858200)

Rindi G, Efrat S, Ghatei MA, Bloom SR, Solcia E \& Polak JM 1991 Glucagonomas of transgenic mice express a wide range of general neuroendocrine markers and bioactive peptides. Virchows Archiv 419 115-129. (https://doi.org/10.1007/BF01600225)

Roche C, Rasolonjanahary R, Thirion S, Goddard I, Fusco A, FigarellaBranger D, Dufour H, Brue T, Franc JL, Enjalbert A, et al. 2012 Inactivation of transcription factor pit-1 to target tumoral somatolactotroph cells. Human Gene Therapy 23 104-114. (https://doi. org/10.1089/hum.2011.105)

Roussel-Gervais A, Bilodeau S, Vallette S, Berthelet F, Lacroix A, FigarellaBranger D, Brue T \& Drouin J 2010 Cooperation between cyclin E and p27(Kip1) in pituitary tumorigenesis. Molecular Endocrinology 24 1835-1845. (https://doi.org/10.1210/me.2010-0091)

Rusner C, Trabert B, Katalinic A, Kieschke J, Emrich K, Stang A \& Network of German Cancer R 2013 Incidence patterns and trends of malignant gonadal and extragonadal germ cell tumors in Germany, 19982008. Cancer Epidemiology 37 370-373. (https://doi.org/10.1016/j. canep.2013.04.003)

Russell JP, Powell DJ, Cunnane M, Greco A, Portella G, Santoro M, Fusco A \& Rothstein JL 2000 The TRK-T1 fusion protein induces neoplastic transformation of thyroid epithelium. Oncogene 19 5729-5735. (https://doi.org/10.1038/sj.onc.1203922)

Russo MA, Kang KS \& Di Cristofano A 2013 The PLK1 inhibitor GSK461364A is effective in poorly differentiated and anaplastic thyroid carcinoma cells, independent of the nature of their driver mutations. Thyroid 23 1284-1293. (https://doi.org/10.1089/thy.2013.0037)

Saez C, Japon MA, Ramos-Morales F, Romero F, Segura DI, Tortolero M \& Pintor-Toro JA $1999 \mathrm{hpttg}$ is over-expressed in pituitary adenomas and other primary epithelial neoplasias. Oncogene 18 5473-5476. (https://doi.org/10.1038/sj.onc.1202914)

Sahut-Barnola I, Lefrancois-Martinez AM, Jean C, Veyssiere G \& Martinez A 2000 Adrenal tumorigenesis targeted by the corticotropinregulated promoter of the aldo-keto reductase AKR1B7 gene in transgenic mice. Endocrine Research 26 885-898. (https://doi. org/10.3109/07435800009048613)

Saunders LR, Bankovich AJ, Anderson WC, Aujay MA, Bheddah S, Black K, Desai R, Escarpe PA, Hampl J, Laysang A, et al. 2015 A DLL3targeted antibody-drug conjugate eradicates high-grade pulmonary neuroendocrine tumor-initiating cells in vivo. Science Translational Medicine 7 302ra136. (https://doi.org/10.1126/scitranslmed.aac9459)

Schaffer BE, Park K-S, Yiu G, Conklin JF, Lin C, Burkhart DL, Karnezis AN Sweet-Cordero EA \& Sage J 2010 Loss of p130 accelerates tumor development in a mouse model for human small-cell lung carcinoma Cancer Research 70 3877-3883. (https://doi.org/10.1158/0008-5472. CAN-09-4228)

Severin GW, Kristensen LK, Nielsen CH, Fonslet J, Jensen AI, Frellsen AF, Jensen KM, Elema DR, Maecke H, Kjaer A, et al. 2017 Neodymium-140 DOTA-LM3: evaluation of an in vivo generator for PET with a non-internalizing vector. Frontiers in Medicine 4 98. (https://doi. org/10.3389/fmed.2017.00098)

Siegel RL, Miller KD \& Jemal A 2018 Cancer statistics, 2018. CA: A Cancer Journal for Clinicians 68 7-30. (https://doi.org/10.3322/caac.21442)

Sikder H, Huso DL, Zhang H, Wang B, Ryu B, Hwang ST, Powell JD \& Alani RM 2003 Disruption of Id1 reveals major differences in angiogenesis between transplanted and autochthonous tumors. Cancer Cell 4 291-299. (https://doi.org/10.1016/S15356108(03)00245-9)

Siolas D \& Hannon GJ 2013 Patient-derived tumor xenografts: transforming clinical samples into mouse models. Cancer Research $\mathbf{7 3}$ 5315-5319. (https://doi.org/10.1158/0008-5472.CAN-13-1069)
Sivanand S, Pena-Llopis S, Zhao H, Kucejova B, Spence P, Pavia-Jimenez A, Yamasaki T, McBride DJ, Gillen J, Wolff NC, et al. 2012 A validated tumorgraft model reveals activity of dovitinib against renal cell carcinoma. Science Translational Medicine 4 137ra175.

Smith-Hicks CL, Sizer KC, Powers JF, Tischler AS \& Costantini F 2000 C-cell hyperplasia, pheochromocytoma and sympathoadrenal malformation in a mouse model of multiple endocrine neoplasia type 2B. EMBO Journal 19 612-622. (https://doi.org/10.1093/ emboj/19.4.612)

Sotillo R, Renner O, Dubus P, Ruiz-Cabello J, Martin-Caballero J, Barbacid M, Carnero A \& Malumbres M 2005 Cooperation between Cdk4 and p27kip1 in tumor development: a preclinical model to evaluate cell cycle inhibitors with therapeutic activity. Cancer Research 65 3846-3852. (https://doi.org/10.1158/0008-5472.CAN-04-4195)

Steele VE \& Lubet RA 2010 The use of animal models for cancer chemoprevention drug development. Seminars in Oncology 37 327-338. (https://doi.org/10.1053/j.seminoncol.2010.05.010)

Stefaneanu L, Rindi G, Horvath E, Murphy D, Polak JM \& Kovacs K 1992 Morphology of adenohypophysial tumors in mice transgenic for vasopressin-SV40 hybrid oncogene. Endocrinology 130 1789-1795.

Stenzel-Poore MP, Cameron VA, Vaughan J, Sawchenko PE \& Vale W 1992 Development of Cushing's syndrome in corticotropin-releasing factor transgenic mice. Endocrinology 130 3378-3386. (https://doi. org/10.1210/endo.130.6.1597149)

Stilling GA, Zhang H, Ruebel KH, Leontovich AA, Jin L, Tanizaki Y, Zhang S, Erickson LA, Hobday T \& Lloyd RV 2007 Characterization of the functional and growth properties of cell lines established from ileal and rectal carcinoid tumors. Endocrine Pathology 18 223-232. (https://doi.org/10.1007/s12022-007-9001-3)

Suzuki H, Willingham MC \& Cheng S-Y 2002 Mice with a mutation in the thyroid hormone receptor beta gene spontaneously develop thyroid carcinoma: a mouse model of thyroid carcinogenesis. Thyroid 12 963-969. (https://doi.org/10.1089/105072502320908295)

Takagi S, Ishikawa Y, Mizutani A, Iwasaki S, Matsumoto S, Kamada Y, Nomura T \& Nakamura K 2017 LSD1 inhibitor T-3775440 inhibits SCLC cell proliferation by disrupting LSD1 interactions with SNAG domain proteins INSM1 and GFI1B. Cancer Research 77 4652-4662. (https://doi.org/10.1158/0008-5472.CAN-16-3502)

Tanaka N, Onda M, Seya T, Kanazawa Y, Naito Z, Asano G \& Oguro T 1999 Establishment and characterization of a human rectal neuroendocrine carcinoma xenograft into nude mice. Digestion 60 117-124. (https://doi.org/10.1159/000007636)

Tentler JJ, Tan AC, Weekes CD, Jimeno A, Leong S, Pitts TM, Arcaroli JJ, Messersmith WA \& Eckhardt SG 2012 Patient-derived tumour xenografts as models for oncology drug development. Nature Reviews Clinical Oncology 9 338-350. (https://doi.org/10.1038/ nrclinonc.2012.61)

Thakker RV 2014 Multiple endocrine neoplasia type 1 (MEN1) and type 4 (MEN4). Molecular and Cellular Endocrinology 386 2-15. (https://doi org/10.1016/j.mce.2013.08.002)

Tsai KY, MacPherson D, Rubinson DA, Nikitin AY, Bronson R, Mercer KL, Crowley D \& Jacks T 2002 ARF mutation accelerates pituitary tumor development in Rb+/- mice. PNAS 99 16865-16870. (https://doi. org/10.1073/pnas.262499599)

Tuttle RL, Gill NS, Pugh W, Lee JP, Koeberlein B, Furth EE, Polonsky KS, Naji A \& Birnbaum MJ 2001 Regulation of pancreatic beta-cell growth and survival by the serine/threonine protein kinase Akt1/PKBalpha. Nature Medicine 7 1133-1137. (https://doi.org/10.1038/nm1001-1133)

Vierimaa O, Georgitsi M, Lehtonen R, Vahteristo P, Kokko A, Raitila A, Tuppurainen K, Ebeling TML, Salmela PI, Paschke R, et al. 2006 Pituitary adenoma predisposition caused by germline mutations in the AIP gene. Science 312 1228-1230. (https://doi.org/10.1126/ science.1126100)

Vitagliano D, Portella G, Troncone G, Francione A, Rossi C, Bruno A, Giorgini A, Coluzzi S, Nappi TC, Rothstein JL, et al. 2006 Thyroid targeting of the N-ras(Gln61Lys) oncogene in transgenic mice results 
in follicular tumors that progress to poorly differentiated carcinomas. Oncogene 25 5467-5474. (https://doi.org/10.1038/sj.onc.1209527)

Vitale G, Gaudenzi G, Circelli L, Manzoni MF, Bassi A, Fioritti N, Faggiano A, Colao A \& Group N 2017 Animal models of medullary thyroid cancer: state of the art and view to the future. EndocrineRelated Cancer 24 R1-R12. (https://doi.org/10.1530/ERC-16-0399)

Vlotides G, Eigler T \& Melmed S 2007 Pituitary tumor-transforming gene: physiology and implications for tumorigenesis. Endocrine Reviews 28 165-186. (https://doi.org/10.1210/er.2006-0042)

Vooijs M, van der Valk M, te Riele H \& Berns A 1998 Flp-mediated tissue-specific inactivation of the retinoblastoma tumor suppressor gene in the mouse. Oncogene 17 1-12. (https://doi.org/10.1038/ sj.onc.1202169)

Vooijs M, Jonkers J, Lyons S \& Berns A 2002 Noninvasive imaging of spontaneous retinoblastoma pathway-dependent tumors in mice. Cancer Research 62 1862-1867.

Wael H, Yoshida R, Kudoh S, Hasegawa K, Niimori-Kita K \& Ito T 2014 Notch1 signaling controls cell proliferation, apoptosis and differentiation in lung carcinoma. Lung Cancer 85 131-140. (https:// doi.org/10.1016/j.lungcan.2014.05.001)

Wang TC, Bonner-Weir S, Oates PS, Chulak M, Simon B, Merlino GT, Schmidt EV \& Brand SJ 1993 Pancreatic gastrin stimulates islet differentiation of transforming growth factor alpha-induced ductular precursor cells. Journal of Clinical Investigation 92 1349-1356. (https:// doi.org/10.1172/JCI116708)

Wang D, Wong HK, Feng YB \& Zhang ZJ 2014 Liquiritigenin exhibits antitumour action in pituitary adenoma cells via Ras/ERKs and ROSdependent mitochondrial signalling pathways. Journal of Pharmacy and Pharmacology 66 408-417. (https://doi.org/10.1111/jphp.12170)

Weber MM, Fottner C, Schmidt P, Brodowski KM, Gittner K, Lahm H, Engelhardt D \& Wolf E 1999 Postnatal overexpression of insulin-like growth factor II in transgenic mice is associated with adrenocortical hyperplasia and enhanced steroidogenesis. Endocrinology 140 1537-1543. (https://doi.org/10.1210/endo.140.4.6660)

Westcott PMK, Halliwill KD, To MD, Rashid M, Rust AG, Keane TM, Delrosario R, Jen K-Y, Gurley KE, Kemp CJ, et al. 2015 The mutational landscapes of genetic and chemical models of Kras-driven lung cancer. Nature 517 489-492. (https://doi.org/10.1038/nature13898)

Wiedemann T \& Pellegata NS 2016 Animal models of multiple endocrine neoplasia. Molecular and Cellular Endocrinology 421 49-59. (https:// doi.org/10.1016/j.mce.2015.07.004)

Wolkersdorfer GW, Bornstein SR, Higginbotham JN, Hiroi N, Vaquero JJ, Green MV, Blaese RM, Aguilera G, Chrousos GP \& Ramsey WJ 2002 A novel approach using transcomplementing adenoviral vectors for gene therapy of adrenocortical cancer. Hormone and Metabolic Research 34 279-287. (https://doi.org/10.1055/s-2002-33255)

Wu Y, Pfeifer AK, Myschetzky R, Garbyal RS, Rasmussen P, Knigge U, Bzorek M, Kristensen MH \& Kjaer A 2013 Induction of anti-tumor immune responses by peptide receptor radionuclide therapy with (177)Lu-DOTATATE in a murine model of a human neuroendocrine tumor. Diagnostics 3 344-355. (https://doi.org/10.3390/ diagnostics3040344)

Yang Z, Zhang L, Serra S, Law C, Wei A, Stockley TL, Ezzat S \& Asa SL 2016 Establishment and characterization of a human neuroendocrine tumor xenograft. Endocrine Pathology 27 97-103. (https://doi. org/10.1007/s12022-016-9429-4)

Yang D, Denny SK, Greenside PG, Chaikovsky AC, Brady JJ, Ouadah Y, Granja JM, Jahchan NS, Lim JS, Kwok S, et al. 2018a Intertumoral heterogeneity in SCLC is influenced by the cell type of origin.
Cancer Discovery 8 1316-1331. (https://doi.org/10.1158/2159-8290. CD-17-0987)

Yang Z, Wang W, Lu J, Pan G, Pan Z, Chen Q, Liu W \& Zhao Y $2018 b$ Gastric neuroendocrine tumors (G-nets): incidence, prognosis and recent trend toward improved survival. Cellular Physiology and Biochemistry 45 389-396. (https://doi.org/10.1159/000486915)

Yeager N, Klein-Szanto A, Kimura S \& Di Cristofano A 2007 Pten loss in the mouse thyroid causes goiter and follicular adenomas: insights into thyroid function and Cowden disease pathogenesis. Cancer Research 67 959-966. (https://doi.org/10.1158/0008-5472.CAN-063524)

Yin Z, Williams-Simons L, Parlow AF, Asa S \& Kirschner LS 2008 Pituitaryspecific knockout of the Carney complex gene Prkar1a leads to pituitary tumorigenesis. Molecular Endocrinology 22 380-387. (https:// doi.org/10.1210/me.2006-0428)

Zeng J, See AP, Aziz K, Thiyagarajan S, Salih T, Gajula RP, Armour M, Phallen J, Terezakis S, Kleinberg L, et al. 2011 Nelfinavir induces radiation sensitization in pituitary adenoma cells. Cancer Biology and Therapy 12 657-663. (https://doi.org/10.4161/cbt.12.7.17172)

Zeng W, Chen X, Ma Y, Huang Z, Qin Y, Wu F, Wu L, Liang X, Qin Y, Zhou J, et al. 2014 A novel approach for enriching cancer stem cells from the human SW-13 adrenocortical carcinoma cell line. Anticancer Research 34 117-123.

Zhang Z, Zhou Y, Qian H, Shao G, Lu X, Chen Q, Sun X, Chen D, Yin R, Zhu H, et al. 2013 Stemness and inducing differentiation of small cell lung cancer NCI-H446 cells. Cell Death and Disease 4 e633. (https:// doi.org/10.1038/cddis.2013.152)

Zhao Y, Xiao Z, Chen W, Yang J, Li T \& Fan B 2015 Disulfiram sensitizes pituitary adenoma cells to temozolomide by regulating O6-methylguanine-DNA methyltransferase expression. Molecular Medicine Reports 12 2313-2322. (https://doi.org/10.3892/ mmr.2015.3664)

Zhen W, Qiu D, Zhiyong C, Xin W, Mengyao J, Dimin Z, Chonghui H, Haijun W \& Yonghong Z 2017 MicroRNA-524-5p functions as a tumor suppressor in a human pituitary tumor-derived cell line. Hormone and Metabolic Research 49 550-557. (https://doi. org/10.1055/s-0043-106437)

Zhou Y, Mokhtari RB, Pan J, Cutz E \& Yeger H 2015 Carbonic anhydrase II mediates malignant behavior of pulmonary neuroendocrine tumors. American Journal of Respiratory Cell and Molecular Biology 52 183-192. (https://doi.org/10.1165/rcmb.2014-0054OC)

Zhu X \& Cheng S-Y 2012 Modeling follicular thyroid cancer for future therapies. American Journal of Cancer Research 2 130-140.

Zhu X, Zhao L, Park JW, Willingham MC \& Cheng SY 2014 Synergistic signaling of KRAS and thyroid hormone receptor beta mutants promotes undifferentiated thyroid cancer through MYC up-regulation. Neoplasia 16 757-769. (https://doi.org/10.1016/j. neo.2014.08.003)

Zindy F, Nilsson LM, Nguyen L, Meunier C, Smeyne RJ, Rehg JE, Eberhart C, Sherr CJ \& Roussel MF 2003 Hemangiosarcomas, medulloblastomas, and other tumors in Ink4c/p53-null mice. Cancer Research 63 5420-5427.

Zitvogel L, Pitt JM, Daillere R, Smyth MJ \& Kroemer G 2016 Mouse models in oncoimmunology. Nature Reviews Cancer 16 759-773. (https://doi.org/10.1038/nrc.2016.91)

Zubair M, Oka S, Parker KL \& Morohashi K-I 2009 Transgenic expression of Ad4BP/SF-1 in fetal adrenal progenitor cells leads to ectopic adrenal formation. Molecular Endocrinology 23 1657-1667. (https://doi. org/10.1210/me.2009-0055)

Received in final form 18 November 2018

Accepted 26 November 2018

Accepted Preprint published online 26 November 2018 https://joe.bioscientifica.com https://doi.org/10.1530/JOE-18-0571 (c) 2019 Society for Endocrinology Published by Bioscientifica Ltd. Printed in Great Britain 